\title{
CRIZA COVID-19: PROVOCĂRI PENTRU PIAŢA MUNCII DIN ROMÂNIA
}

SIMONA ILIE

\begin{abstract}
Tucrarea aduce in atenție impactul contextului COVID-19 asupra pieței muncii. Pe baza analizei secundare de date, este schițată o clasificare a ramurilor economice privind riscul de afectare a activității. Riscul mai mare tinde să se adauge altor vulnerabilități ale ocupării pe ramură (nivel salarial mai redus, ocupare pe cont propriu mai extinsă). Protecția ocupării și a veniturilor realizată în spațiul românesc se dovedește rezonantă practicilor europene ale actualului context, dar în risc de a nu răspunde adecvat accentuării sărăciei și inegalității.

Cuvinte-cheie: inegalităti piata muncii; politici sociale; COVID-19.
\end{abstract}

\section{INTRODUCERE}

La sfârșitul anului 2019 România privea cu curiozitate știrile care veneau din China, despre localități închise, urmare a unui nou tip de virus care afecta populația. La începutul anului 2020, lumea și-a întors brusc privirea spre Italia, unde nordul și apoi sudul țării păreau a nu putea controla extinderea aceluiași virus. Până să înțeleagă bine situaţia, românii s-au văzut în faţa unui val de vești neliniștitoare din Europa și Orientul apropiat, a primelor recomandări de distanțare socială, a primelor cazuri de infectare a populației cu noul virus în spațiul naţional, ca și a creșterii fluxului de revenire în țară a celor ce munceau în afara granițelor.

La mijlocul lunii martie România se afla în fața primei Ordonanțe Militare din timpuri recente, care impunea distanţarea socială și suspenda activități sociale şi economice. La sfârșitul lunii martie toate țările europene erau sub restricții de distanțare socială, mai mult sau mai puțin severe, se monitoriza presiunea asupra sistemului sanitar național și se demaraseră măsuri de contracarare a recesiunii economice care se anunța. Dacă inițial nu păreau să existe motive de rememorare a crizei economice din 2009-2010, la o lună de la accelerarea numărului de îmbolnăviri a devenit evident că actualul context va fi urmat de o recesiune, poate chiar mai severă decât cea din urmă cu un deceniu.

Adresa de contact a autorului: Simona Ilie, Institutul de Cercetare a Calităţii Vieţii al Academiei Române, Calea 13 Septembrie, nr. 13, sector 5, 050711, Bucureşti, România, e-mail: sf_ilie@yahoo.co.uk. 
Prezenta lucrare a prins contur în cadrul unui demers instituțional de cercetare ${ }^{1}$, privind practici internaționale menite să susțină ocuparea și veniturile populației, ca răspuns la actualul context de criză. Documentarea realizată de autor cu acea ocazie este prefațată aici de analiza impactului crizei asupra pieței muncii, care se profila inegal din chiar formularea restricțiilor.

Lucrarea este structurată în două secțiuni. Prima secțiune descrie condițiile care conduc la expunerea diferită a domeniilor economice la riscul restrângerii activității, urmată de o analiză a profilului ocupării pe ramuri. Ce-a de-a doua constă în comparația răspunsului politicilor sociale. Măsurile de suport formulate în contextul pandemic al COVID-19 în România sunt analizate prin raportare la contextul românesc al crizei din 2009/2010, ca și la practici ale câtorva țări europene în contextul actual. Capitolul concluziv subliniază vulnerabilitatea ocupării din România, ca și posibile oportunități ale actualului context.

\section{REPERE TEORETICE SI METODOLOGIE}

Într-una dintre primele lucrări care adresează contextul COVID-19, Baldwin și Weder di Mauro (2020) punctează relația inversă dintre viteza și gradul de răspândire a virusului și severitatea crizei economice asociate. Monitorizarea non-restrictivă conduce la îmbolnăviri pe scară largă, cu riscul depășirii capacității de răspuns a sistemului medical. În timp, pierderea capacității de muncă a unui segment larg al forței de muncă se va resimți și în economie. Alternativ, măsuri severe de distanțare socială au beneficiul temperării numărului de îmbolnăviri, cu prețul unui impact negativ accentuat și imediat asupra mediului economic. Autorii numesc chiar alternativa recesiunii imediate o măsură necesară de sănătate publică (2020: 8-9).

Natura muncii și forma concretă de executare a profesiilor expun diferit populația ocupată la riscul de contagiune. Prin urmare, unele ramuri sunt mai expuse riscului de restrângere a activităţii decât altele. Biroul Internațional al Muncii (BIM) schițează o clasificare a ramurilor după acest criteriu, pe cinci grade de risc. Cel mai mare risc îl au comerțul, industria prelucrătoare, industria hotelieră și de alimentație publică, respectiv domeniul imobiliar și serviciile administrative pentru firme. Cel mai mic risc este în domeniul medical, învățământ, servicii de utilităţi publice, precum și administrația publică și apărarea (ILO, 2020). Lucrarea BIM atrage atenția și asupra riscurilor suplimentare care se conturează pentru ocuparea pe cont propriu și cea informală: prima, urmare a capacităţii financiare mult reduse de a supraviețui în condițiile restrângerii activității, iar ce-a de-a doua, prin absența asigurărilor sociale de sănătate și șomaj.

\footnotetext{
${ }^{1}$ Mulțumesc colegilor S. Stănescu, A. M. Preoteasa și lui F. Alexandrescu pentru sugestiile făcute pe durata elaborării lucrării.
} 
Temperarea efectelor economice de durată ale unui astfel de şoc își găsește răspuns într-un set complex de măsuri. Măsuri de control a răspândirii virusului trebuie acompaniate de măsuri fiscal-monetare, sociale, de dezvoltare industrială și comercială (Baldwin şi Weder di Mauro, 2020; ILO, 2020). În paleta intervențiilor concrete, BIM recomandă împrumuturi pentru diferite sectoare economice, inclusiv cel medical, facilităţi fiscale pentru companii, flexibilizarea relaţiilor de muncă pentru conformarea la condițiile impuse, extinderea accesului la concediu plătit și servicii de sănătate, extinderea protecției sociale, inclusiv pentru cei vulnerabili, precum și creșterea rolului dialogului social, pentru identificarea de soluții. Relaxarea restricțiilor UE cu privire la nivelul datoriei și deficitului bugetar al statelor membre, formularea cadrului general al măsurilor temporare de ajutor de stat pentru susținerea economiilor naționale (TFEU) și alocarea financiară în acest scop ${ }^{2}$, anunțate în a doua parte a lunii martie de către Comisia Europeană, sunt consonante unei astfel de intervenții complexe. Accentul este de așteptat să cadă pe domenii direct afectate, cu risc de suspendare temporară a activității, respectiv întreprinderi mici și mijlocii. Provocarea statelor este de a găsi combinația optimă a acestor măsuri în funcție de profilul național și momentul formulării lor, pentru a ține sub control amplificarea și persistența efectelor negative ale suspendării activității asupra nivelului de trai și pentru a evita falimentul de țară.

Articolul de față schițează o clasificare a ramurilor economice asemănătoare BIM, adaptată contextului naţional. În acest cadru este analizat profilul ocupării în relație cu nivelul de salarizare, natura ocupării și distribuția teritorială a ramurilor. În analiza politicilor sociale, lucrarea se concentrează pe măsurile formulate în prima lună de la activarea stării de urgență, și marginal ulterior, folosind analiza secundară de date, comunicate ale instituțiilor naționale și internaţionale transmise pe site-uri oficiale sau informații de presă cu privire la măsuri implementate. În identificarea măsurilor de protecție a ocupării și veniturilor în spațiul internațional am urmărit selecția unor țări europene cu ideologii diferite în relație cu piața muncii și protecția socială, lucru realizat în măsura în care documentarea a permis obținerea de informații sugestive pentru profilul intervenției curente, și nu doar măsuri disparate.

\section{DISTANŢAREA SOCIALĂ: IMPACT ASUPRA PIEȚEI ROMÂNEŞTI A MUNCII}

\section{Ajustarea activității economice și gradul de risc}

Relaționarea interumană fizică, directă poartă în contextul noului virus riscul infectării. Prin urmare, primele măsuri de control a răspândirii virusului au constat în recomandări sanitare de prevenție și distanțare socială. Acestea trebuiau aplicate

\footnotetext{
${ }^{2}$ https://ec.europa.eu/commission/presscorner/detail/en/ip_20_499.
} 
deopotrivă de către populație și companii, în activitatea cotidiană și profesională, prin utilizarea de dezinfectanți, măști, mănuși și, după caz, scuturi faciale sau paravane separatoare. Distanțarea socială s-a tradus prin creșterea distanței fizice între persoane în spaţii publice, reducerea deplasărilor și activităților ne-esențiale, izolarea persoanelor care veneau din țări cu răspândire mai accentuată a virusului, a celor care manifestau simptomatologie specifică, ca și a celor care intraseră în contact cu aceștia. Pornind de la actul legislativ care le reglementa (OM1/2020) și de la modul de operaționalizare a măsurilor în activitatea profesională, s-au conturat câteva grupe de domenii-activități, astfel:

- Domenii cu risc ridicat de contagiune, unde natura activităţii presupune prezența unui număr mare de persoane în spațiu restrâns, care și-au restricționat sever sau și-au suspendat temporar activitatea. Între acestea se regăsesc organizarea de evenimente cultural-artistice, evenimente sportive (de performanță, recreative), industria de ospitalitate, turism de agrement și balnear în spații închise, comerțul nealimentar în formă clasică, transportul de călători, activitatea în unități de învățământ.

- O grupă eterogenă de domenii fără risc ridicat de contagiune, care şi-au redus activitatea pentru că: a) nu se putea monitoriza diversitatea contactelor persoanelor care interacționau (ex.: servicii de înfrumusețare, cabinete stomatologice, domeniul imobiliar, construcții, servicii la domiciliu); b) aveau nevoie de timp și cheltuieli pentru dotarea cu accesorii de protecție și eventual re-segmentarea spațiului de lucru (ex.: parte a industriei producătoare auto); c) partenerii economici și-au restrâns activitatea.

- Domenii esențiale existenței sau gestionării sanitare și economice pe timp de pandemie, cu risc scăzut de afectare a activității, precum domeniul medical, industria alimentară și agricultura, industria farmaceutică, de produse sanitare, instrumentar și echipamente medicale, industria energetică și a carburanților, servicii de utilități publice, siguranța publică și, cel puțin parțial, administrația publică centrală și locală.

$\mathrm{Cu}$ câteva excepții, această grupare nu este disjunctivă sau definitivă, subdiviziunile unui domeniu putându-se afla în grupe diferite, după cum, în timp, unele firme pot migra între grupe. Odată ce cererea anumitor produse de primă necesitate a crescut (în unele cazuri ca urmare a scăderii importurilor) și-au afirmat caracterul esențial și industria și cercetarea națională a produselor chimice (dezinfectanţi şi produse de curățat), mică industrie de textile şi confecții (măşti), mică producție de echipamente și/sau mase plastice (ex.: separatoare și viziere) cu potențială utilizare medicală. Guvernul a acceptat oferta internă de acest tip sub condiția respectării unor cerințe specifice de fabricație.

A existat și o grupă a câștigătorilor în criza COVID-19. Aflate sau nu în domenii cu risc ridicat de contagiune, regăsim aici activităţile pentru care tehnologia a permis translatarea lor în spaţiul personal sau care s-au putut organiza, 
repede și fără costuri mari, în forme adecvate cerințelor de protecție epidemică: activităţi din domeniul IT, activități practicate pe scară largă în forme independente (jurnaliști, servicii profesionale, consultanță de orice natură), servicii de catering și curierat, dar și domenii care, până la acest context, au integrat mai puțin activitatea online specificului muncii lor. Între cei din urmă regăsim profesori și educatori, judecători, artiști și alte meserii/ocupații specifice domeniului de divertisment, antrenori sportivi, personal în servicii administrative - agenți economici, care au avut infrastructura, creativitatea sau flexibilitatea de a-și adapta munca la imperativul situației. Astfel de exemple sunt:

- Platformele online (,piață”) pentru produsele micilor producători; fără să fie o noutate, această cale a devenit mai larg accesată pentru promovarea și comercializarea produselor lor, odată ce forme clasice de tipul târgurilor sau rețelelor personale, de nișă, au fost sistate. Activitatea de comerț online (de produse alimentare și nealimentare), activități de curierat și livrări la domiciliu, cu platforme pre-existente și, asociat, producția de ambalaje, au crescut sensibil ${ }^{3}$.

- Experiența dobândită în învățământul universitar la distanță (platforme tehnice de comunicare, adaptarea stilului de comunicare și elaborarea suporturilor de curs, drepturi de copyright pentru acestea) a fost extinsă la cursanții la zi. Deschiderea în învățământul preuniversitar a fost impulsionată de presiunea examenelor de final a ciclurilor școlare, dar a fost condiționată de profilul unității de învăţământ, accesul elevilor la infrastructura specifică, ca și de creativitatea cadrelor didactice de a adapta curricula la procesul educativ online și de a-i valorifica oportunitățile. În învățământul primar și secundar inferior, rețelele copiilor sau ale părinților lor s-au consolidat și au completat platforma oferită de Ministerul Educației pentru menținerea procesului educativ. Oferta privată a adăugat acestora diverse servicii/ activităţi online cu caracter educativ pentru copii sub 10 ani (ora de povești, jocuri).

- Evenimente culturale (teatre, tururi virtuale ale muzeelor, concerte și recitaluri) au fost „deschise” publicului online.

- Accesul electronic al părților implicate într-o anumită cauză juridică la dosarul digitalizat este posibil de acum câțiva ani, dar a fost amplificat în acest context. Opțiunea apelului la video-conferință în cauze în care sunt implicați deținuți există, de asemenea, de câțiva ani, fiind explicit menită să reducă costurile Administrației Penitenciarelor ocazionate de transportul deținuților la Instanțe.

${ }^{3}$ Angajăm 100 de oameni și pregătim lansarea unui nou serviciu de livrări în zona de alimente, Conrea R./9.04.2020; Producătorii de ambalaje, la foc continuu: este critic să ne servim clienții, pentru ca aceștia să poată răspunde nevoilor societății, Vasiliu A.E./13.04.2020; Farmec a demarat producţia de biocide în fabrica din Cluj-Napoca. Mircea Turdean, CEO: Ne-am adaptat liniile de producţie prioritizând produsele de dezinfectat, pentru a răspunde nevoilor din piaţă, Bellu C./ 29.04.2020; Mediul de afaceri: acum este cel mai bun moment să acționăm. Oportunitatea acestei crize ar putea fi să transformăm importurile în produse românești, Niţu F., Cornea R./1.05.2020, Ziarul financiar, www.zf.ro. 
Utilizat marginal până la actuala conjunctură, sistemul (cu investiții semnificative) este singura formă posibilă de comunicare cu familia și larg utilizată în cazul termenelor la Instanță pe care le au deținuții, odată ce contactul cu mediul exterior a fost sever restricționat. Caracter de noutate are derularea online a unora dintre ședințele de judecată sau dintre cele parlamentare.

- Sesiuni de activități de întreținere fizică (pilates, kinetoterapie, gimnastică de întreținere) via online sunt mult mai la îndemână de realizat la ore târzii sau matinale. $\mathrm{Cu}$ siguranță acesta va fi un contrarăspuns la programul prelungit al sălilor de sport, singurul care răspundea până acum cererii celor cu program de muncă fix (9-18).

Prin descompunerea acestui tablou după criterii precum numărul de persoane care interferează la un moment dat prin natura profesiei, numărul de persoane afectat direct de ajustarea activității, timpul necesar adaptării locului de muncă și posibilitatea de a implementa cerinţele sanitare și de distanțare socială, posibilitatea derulării activității de la distanță, oportunitățile și imperativul activităţii în gestionarea situației actuale am schițat gradul de risc al reducerii activității pentru ramurile economice și câteva dintre sub-ramurile direct vizate de prezentul context (Anexa 1). Gradul 5 revine domeniilor cel mai expuse. Ierarhia nu este identică celei formulate de ILO (2020), contexte naționale diferite putând conduce la expuneri diferite ale ramurilor la riscul de reducere a activității. De notorietate este cazul Suediei, unde perioada de criză a fost abordată cu restrângerea minimală a activităţii economice, chiar în ramuri de regulă asociate unui risc ridicat de închidere (ex.: restaurante, baruri, cafenele).

Totuși, tendința dominantă a fost de reducere a activității și pierderea locurilor de muncă. Studiul ad-hoc al Institutului Național de Statistică (INS, 2020a), realizat în a doua jumătate a lunii martie, estima o reducere de $30 \%$ a PIB pentru luna martie și o continuare a scăderii până la $40 \%$ în aprilie. De asemenea, procentul celor care prognozau că activitatea lor nu va fi deloc afectată a scăzut la jumătate între martie și aprilie (de la 12,9\% la 6,4\%), paralel cu creșterea incertitudinii privind evoluția afacerii lor. În industria prelucrătoare, ca și în transporturi și depozitare, incertitudinea a crescut de la cca $25 \%$ la $40 \%$ (o serie de sub-ramuri dependente fiind de importuri), iar în construcții și comerț de la cca. $21 \%$ la $33 \%$. În domeniul hotelurilor și restaurantelor indecizia a fost cea mai scăzută (11,7\%, respectiv $27,8 \%)$, dar doar $6 \%$ dintre cei care au putut prognoza evoluția activității estimau o reducere mai mică de $25 \%$ a acesteia sau deloc (față de cca. $78 \%$ în comerț).

Statistici oficiale ale lunii martie și aprilie confirmă aceste dinamici. Activitatea turistică a scăzut cu peste $50 \%$ în luna martie (INS, 2020b), iar comerțul a înregistrat dinamici diferite pe sub-domenii (INS, 2020c): o relativă constanţă a vânzării produselor alimentare și băuturilor, ca și a produselor farmaceutice și cosmeticelor, dar scăderi la comerțul nealimentar (până la jumătate, în cazul produselor de îmbrăcăminte, încălțăminte și textile). Dinamica a fost diferențiată după tipul locației, cu scăderi ale vânzărilor în magazine specializate, chiar și în cazul produselor 
alimentare, și creșteri în cele nespecializate sau cu vânzare prin platforme online (cu 5 p.p. în cazul ultimelor).

Statistica Ministerului Muncii și Protecției sociale (MMPS) privind contractele de muncă afectate (Grafic 1) surprinde creșterea accelerată a numărului acestora în prima jumătate a lunii aprilie și o stagnare ulterior. Numărul mediu zilnic al contractelor afectate a fost de 1,24 milioane în cea de-a doua parte a lunii aprilie, ceea ce reprezintă aproape un sfert din numărul total de salariați activi din luna martie (MMPS). 275 mii dintre contractele afectate erau contracte încetate, egalând în mai puțin de două luni scăderea netă a numărului de salariați pe întreg anul 2009 (272 mii; INS_FOM104B). În timp ce suspendarea contractelor se restrânge la debutul lunii mai, odată cu reluarea treptată a activității economice, alternativa încetării relațiilor contractuale își continuă creșterea, validând prognoza unui impact economic negativ de durată a pandemiei COVID-19, și nu doar dificultăți de moment. De-a lungul întregii perioade, contractele suspendate din industria prelucrătoare, comerț şi din domeniul hotelurilor și restaurantelor au reprezentat cca. $60 \%$ din total $(30 \%$, $19 \%$, respectiv 12\%), în timp ce jumătate dintre cele încetate erau din comerț, industria prelucrătoare și construcții $(19 \%, 17 \%$, respectiv 14\%).

Grafic 1

Contracte afectate în România în contextul COVID-19, 30 martie - 25 mai 2020 (mii)

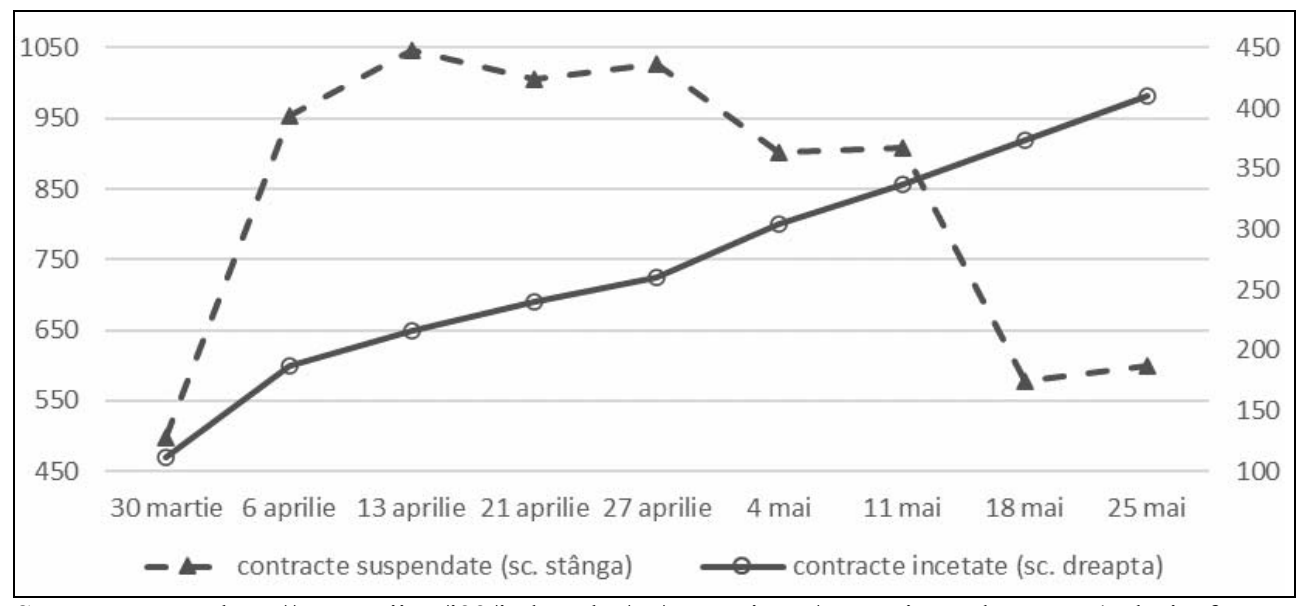

Sursa: MMPS, http://mmuncii.ro/j33/index.php/ro/comunicare/comunicate-de-presa (valori aferente începutului de săptămână).

\section{Profilul domeniului după gradul de risc}

Industria prelucrătoare cuprinde aproape un sfert din numărul total de salariați, are $30 \%$ din ocupare realizată în forme non-salariale, un risc ridicat de închidere pe ansamblu, dar eterogenitate ridicată pe industrii componente (Anexa 1). Chiar industrii ne-expuse riscului de reducere a activității, care pot găsi în prezentul context 
un impuls pentru dezvoltare, cum sunt industria alimentară și cea farmaceutică, au profiluri diferite; prima cuprinde 3\% din totalul salariaților, la un nivel salarial mediu mai mic cu cca. 30\% decât cel naţional, iar cea de-a doua cuprinde doar $0,2 \%$ dintre salariați, la un nivel salarial cu cca. $25 \%$ mai mare decât media națională.

Comerțul are o prezență a salariaților în ocuparea totală a ramurii și un nivel salarial mediu apropiat industriei prelucrătoare pe ansamblu, dar cuprinde doar $17 \%$ din totalul salariaților. $\mathrm{Cu}$ și mai mică pondere a salariaţilor în ocuparea totală a ramurii, domeniul construcțiilor are, alături de activitățile de curierat și industria de ospitalitate, cele mai mici niveluri salariale. În plus construcțiile, comerțul, serviciile pentru gospodării private, ca și agricultura au o mai mare expunere la ocuparea de tip informal (Stănculescu, Marin și Hommes, 2009).

Eterogenitate în dinamica diferitelor sub-ramuri componente regăsim și în industria transporturilor, unde activitatea de postă şi curierat se grupează cu cea diversă de transporturi și depozitare. Sub-ramura de poștă și curierat prezintă ea însăși evoluții divergente; numărul de salariați ai activității de poștă tradiţională s-a redus la momentul restructurării sectorului (2013), în timp ce activitatea de curierat este pe o pantă ascendentă, odată cu creșterea comerțului online. Industria de informații și comunicații cuprinde sectorul serviciilor informatice, dar și telecomunicații sau servicii de tipărire și cinematografice, de unde și riscul mai mare de închidere și nivelul de salarizare mai mic la nivelul întregii ramuri.

Între ramurile cu activitate puternic restricționată, industria cultural-artistică are o situație particulară; prezenta criză survine după o decadă de dezvoltare accentuată a ramurii (numărul de salariați fiind în 2018 cu peste $80 \%$ mai mare decât în 2008; INS_FOM104F), având în plus o pondere a ocupării salariale în total și niveluri salariale mai mari decât alte ramuri cu risc ridicat de restrângere a activității.

Pe ansamblu însă, riscul de reducere a activităţii este mai mare în domenii cu salarizare mai scăzută. Astfel de relații se regăsesc și dincolo de spațiul românesc. Un studiu britanic surprinde faptul că $34 \%$ dintre salariații cu salarii la nivelul celor mai mici 10\% lucrează în sectoare care s-au închis în contextul crizei COVID-19, față de numai 5\% dintre cei din grupa cu cele mai mari 10\% salarii (Joyce și Xu, 2020). Datele Biroului de Statistică a Muncii din $\mathrm{SUA}^{4}$ arată că dintre cei mai săraci $25 \%$ doar $9,2 \%$ au locuri de muncă care le permit să lucreze de acasă, în timp ce pentru cei mai bogați $25 \%$ acest procent este de $61 \%$.

$\mathrm{Cu}$ câteva excepții (ex.: ind. farmaceutică), subramurile observate sunt prezente în toate regiunile țării, dar o industrie poate contribui mai mult sau mai puțin la ocuparea salarială a regiunii și, prin urmare, o regiune poate fi în avantaj/ dezavantaj relativ în raport cu situația națională.

\footnotetext{
${ }^{4}$ These are the occupations with the highest COVID-19 risk, Marcus Lu, 20 April 2020, World economic forum and Visual Capitalist https://www.weforum.org/agenda/2020/04/occupations-highestcovid19-risk/.
} 
Anexa 1 indică şi supra-reprezentarea ${ }^{5}$ regională a unora dintre ramuri. Cel mai mare ecart față de situaţia națională se găsește în regiunea București-Ilfov, unde sunt aproape $22 \%$ din numărul total al salariaților din țară, dar $42 \%$ dintre salariații industriei produselor și preparatelor farmaceutice, $44 \%$ dintre cei din servicii informatice și suport IT, 46\% dintre cei cu activități profesionale și științifice, respectiv 49\% dintre cei activi în servicii financiare. Prezența mai extinsă a domeniilor cu salarizare mai ridicată face ca salariul mediu să fie aici cu $35 \%$ mai mare decât media națională, toate celelalte regiuni având un nivel salarial sub acest nivel.

Observate după regiuni de dezvoltare se conturează chiar o relație directă între riscul reducerii activității și cel de sărăcie al regiunii, alături de un nivel mai ridicat al ocupării nesalariale și chiar informale (Tabelul $n r .1$ ).

Tabelul $n r .1$

Nivel de trai și profilul ocupări după regiune

\begin{tabular}{|c|c|c|c|c|c|c|c|c|c|}
\hline An & Indicator & B-IF & $\mathbf{V}$ & $\mathbf{N V}$ & $\mathbf{C}$ & $\mathbf{S}$ & $\mathbf{S E}$ & SV & NE \\
\hline \multirow{6}{*}{$\stackrel{\infty}{\stackrel{4}{\sim}}$} & Rata riscului de sărăcie relativă, \% & 4 & 15 & 18 & 19 & 26 & 32 & 34 & 36 \\
\hline & $\begin{array}{l}\text { \% populație } 15 \text { ani și peste a regiunii } \\
\text { în total populație corespondentă }\end{array}$ & 12 & 9 & 13 & 12 & 15 & 12 & 10 & 16 \\
\hline & \% salariați ai regiunii în total salariați & 22 & 10 & 14 & 13 & 12 & 11 & 8 & 11 \\
\hline & Rata de ocupare $15-64, \%$ & 71 & 60 & 67 & 59 & 64 & 59 & 63 & 72 \\
\hline & \% salariați în total ocupare & 80 & 64 & 59 & 62 & 53 & 57 & 51 & 50 \\
\hline & $\begin{array}{l}\text { \%, salariul regiunii față de media } \\
\text { națională }\end{array}$ & 135 & 96 & 92 & 93 & 90 & 85 & 88 & 88 \\
\hline \multirow{2}{*}{ 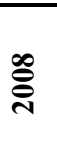 } & $\begin{array}{l}\text { \% populație ocupată cu venituri doar } \\
\text { din activități formale (înregistrate) }\end{array}$ & 92 & 68 & 58 & 53 & 42 & 57 & 39 & 32 \\
\hline & $\begin{array}{l}\text { \% populație ocupată cu venituri doar } \\
\text { informale sau consum din gospodărie }\end{array}$ & 4 & 23 & 31 & 31 & 45 & 34 & 51 & 60 \\
\hline
\end{tabular}

Sursa: INS_SAR102D,_AMG156E,_POP106A,_FOM106E,_FOM104F; Stănculescu, Marin, Hommes, 2009.

Mai larg prezentă în regiunile sărace (NE, SE, SV şi S), agricultura este un domeniu al ocupării nesalariale, aceasta reprezintând $93 \%$ din totalul ocupării pe ramură. Deși se regăsește între domeniile esențiale, veniturile din ocuparea agricolă au fost în risc de reducere; inconstanța în calitate, şi imposibilitatea asigurării unui flux de aprovizionare continuu sau semnificativ au făcut ca desfacerea producției micului producător agricol să se realizeze mai frecvent în piețe tradiționale, prin mici rețele proprii sau relații individuale cu locații de alimentație publică, forme care au tins să

${ }^{5}$ Celulele marcate indică prezența mai extinsă a ramurii în regiune comparativ cu extinderea sa națională, exprimată prin ponderea salariaților ramurii în totalul salariaților. Cele marcate cu „X” și hașurate indică o pondere a salariaților ramurii în regiune cu minim 3.5 p.p. mai mare decât ponderea salariaţilor ramurii la nivel naţional, iar cele marcate cu „x” o pondere mai mare de 1 punct procentual, dar nu mai mare de 3-4 p.p. 
se restrângă în actualul context. Condițiile climatice nefavorabile din ultima jumătate de an au afectat sever, în plus, producția și veniturile acestui domeniu.

\section{RĂSPUNSUL POLITICILOR SOCIALE ÎN CONTEXTE DE CRIZĂ}

\section{Repere ale politicii sociale românești după criza financiară}

La izbucnirea crizei COVID-19, ecourile celei din 2009/2010 abia se stinseseră. Ca și acum, criza din urmă cu un deceniu a survenit după câțiva ani consecutivi de creștere economică. Propagarea efectelor crizei și politica de răspuns în cele două contexte tind însă să difere.

În 2009-2010 riscul crizei economice s-a conturat cu un an înainte, în timp ce acum în doar 2-3 luni. Cu zece ani în urmă recesiunea s-a resimțit treptat, dar egal în raport cu ramurile economice, în timp ce acum a avut un impact diferențiat.

Protecția socială s-a realizat în urmă cu un deceniu prin majorarea sensibilă a salariul minim (2009), două indexări ale punctului de pensie și introducerea a ceea ce astăzi se numește indemnizația socială minimă a pensionarilor (2009), măsuri care au urmat unor creșteri semnificative ale pensiilor în perioada 2007-2008 (Tabelul $n r$. 2). Primul expus crizei a fost sectorul privat, prin disponibilizări. Cel public a reacționat un an mai târziu, prin scăderi salariale cu $25 \%$ pentru tot personalul angajat (sume ce urmau a fi returnate gradual, în următorul an, pe măsură ce economia avea să se stabilizeze). La acestea s-au adăugat revizuirea sistemului de sporuri şi limitarea angajărilor în sectorul public, a simultaneității pensiei cu salariul, precum și severe reevaluări și reformări ale sistemului de suport asistențial (2010-2011). România s-a găsit în jumătatea țărilor europene care au traversat criza financiară din 2008 în condiții de reducere a inegalității în veniturile populației (Eurostat, tessi190 și Tabelul nr. 2).

Contextul economic al anului 2020 se contura mai optimist. În 2018 (ultimele date anuale integral disponibile) nivelul ocupării a ajuns la cote anterioare crizei din 2008; numărul salariaţilor a crescut până la 5,42 milioane persoane în 2018, respectiv până la 5,61 milioane salariați activi în martie 2020 (INS_FOM105G; MMPS) ${ }^{6}$. După reluarea creșterii economice (2014) salariul minim a fost majorat până la de peste 2,8 ori nivelul anului 2008. Au fost luate și măsuri explicite pentru reducerea migrației externe pe câteva categorii profesionale: niveluri superioare ale salariului minim pentru tinerii cu studii superioare și pentru muncitorii în construcții (2019), precum și creșteri salariale semnificative pentru personalul medical (2018). Creșterea pensiilor marii majorității a pensionarilor s-a menținut apropiat ritmului creșterii PIB, dar ajutorul de şomaj şi venitul minim garantat au ieșit din sfera de atenție în contextul economic favorabil al ultimilor ani: determinate ca procent dintr-un referențial nemodificat din 2011, ajutorul mediu de

\footnotetext{
${ }^{6} \mathrm{http}: / /$ mmuncii.ro/j33/index.php/ro/transparenta/statistici (accesat 20.04.2020)
} 
șomaj (pentru care se califică cei căror contract de muncă a încetat în contextul COVID-19) reprezenta, în 2018, mai puțin de un sfert din nivelul salariul minim brut, iar venitul minim garantat (pentru care se califică cei cu acces doar la activități informale) cca. 7\%. În mijlocul unor dispute electorale, alocaţia pentru copii s-a majorat semnificativ în 2019, până la aproximativ nivelul venitului minim garantat, și se discută majorări suplimentare pentru anul în curs. Aceste dinamici, adăugate suspendării unor restricții ocazionate de criza anterioară, ca și unor prevederi foarte avantajoase pentru câteva categorii profesionale (Ilie, 2018) au adus nivelul inegalităţii de venit la cote anterioare crizei financiare.

Tabelul nr. 2

Dinamica principalelor surse de venit ale populației, \%

\begin{tabular}{|l|c|c|c|c|c|c|}
\hline & $\mathbf{2 0 0 6}$ & $\mathbf{2 0 0 8}$ & $\mathbf{2 0 1 0}$ & $\mathbf{2 0 1 7}$ & $\mathbf{2 0 1 8}$ & $\mathbf{2 0 1 9}$ \\
\hline Indicele Gini & - & 0,359 & 0,335 & 0,331 & 0,351 & 0,348 \\
\hline \multicolumn{7}{|l|}{ \% față 2008 (valori ajustate la inflație) } \\
\hline Produs Intern Brut & 70 & 100 & 89 & 131 & 139 & - \\
\hline Salariul mediu net & 75 & 100 & 95 & 140 & 151 & 168 \\
\hline Salariul minim brut (mediu anual) & 73 & 100 & 105 & 220 & 279 & 294 \\
\hline Pensii medie asigurări sociale de stat & 59 & 100 & 111 & 136 & 142 & 152 \\
\hline Pensie medie foști agricultori & 52 & 100 & 109 & 131 & 137 & 146 \\
\hline \multicolumn{7}{|l|}{ \% față de salariul minim brut } \\
$\begin{array}{l}\text { Ajutor șomaj pentru șomeri cu experiență } \\
\text { de muncă }\end{array}$ & 78 & 79 & 78 & 32 & 24 & $(21)^{*}$ \\
\hline Alocație copii & 7,6 & 7,6 & 7,0 & 5,9 & 4,4 & 6,7 \\
\hline Venit minim garantat & 27,9 & 19,6 & 20,8 & 9,9 & 7,4 & 6,8 \\
\hline
\end{tabular}

Surse: Eurostat, tessi190; prelucrări după date INS, CNPP, MMPS; * date provizorii.

Tabelul nr. 3

Persoane asigurate după nivelul venitului brut asigurat, februarie 2020, \%

\begin{tabular}{|l|c|c|c|c|}
\hline & $\begin{array}{c}\text { Cu contract, } \\
\text { normă întreagă }\end{array}$ & $\begin{array}{c}\text { Cu contract, } \\
\text { timp parțial }\end{array}$ & $\begin{array}{c}\text { Alte forme de } \\
\text { asigurare }\end{array}$ & $\begin{array}{c}\text { Total asigurați pe } \\
\text { tranșă de venit }\end{array}$ \\
\hline $\begin{array}{l}\text { \% categorie din total } \\
\text { asigurați }\end{array}$ & 88,4 & 7,6 & 4,0 & 100,0 \\
\hline $\begin{array}{l}\text { La/ sub salariul } \\
\text { minim (105\%) }\end{array}$ & 25,8 & 74,2 & 89,4 & 30,8 \\
\hline $\begin{array}{l}(105-134 \%] \text { salariul } \\
\text { minim }\end{array}$ & 13,1 & 6,6 & 2,5 & 12,2 \\
\hline $\begin{array}{l}\text { Sub 2/3 (67\%) din } \\
\text { salariul mediu brut }\end{array}$ & 52,7 & 85,3 & 93,3 & 56,8 \\
\hline $\begin{array}{l}\text { Peste salariul mediu } \\
\text { brut (>104\%) }\end{array}$ & 26,0 & 7,9 & 4,7 & 23,7 \\
\hline
\end{tabular}

Sursa: date și prelucrări după CNPP (Casa Naţională de Pensii Publice).

Notă: nu includ persoanele care în timpul lunii au primit doar îndemnizație pentru incapacitate temporară de muncă. 
Creșterea accelerată a salariului minim a dus la aglomerarea a $25 \%$ dintre asigurații cu contracte de muncă cu normă întreagă (cca. 1,3 milioane persoane) la venituri în vecinătatea salariului minim. Acest procent crește la $30 \%$, dacă avem în vedere și contractele cu timp parțial și alte forme de asigurare pentru drepturi de pensie în sistemul public, al căror nivel minim al asigurării este în relație cu cel asigurat prin salariul minim național (Tabelul $n r .3$ ).

\section{Protecția ocupării și veniturilor în contextul COVID-19: România}

Măsura centrală de suport în criza COVID-19 a fost finanțarea din fonduri publice a șomajului tehnic pentru cei direct afectați de măsurile restrictive; măsura pre-exista acestui moment, dar finanțarea sa se făcea din fondurile angajatorului. Măsura se adresează tuturor firmelor, indiferent de mărime, acoperă doar perioada stării de urgență, timp în care se menține obligativitatea plății impozitelor și contribuțiilor sociale. În forma ajustată aceasta se adresează atât forței de muncă, cât și angajatorilor, ajutați astfel să supraviețuiască în condiții de dificultăți economice. Angajatorii care nu activează în domenii direct afectate, dar a căror activitate a scăzut ca urmare a condițiilor stării de urgență, pot acorda alocații de șomaj tehnic doar pentru $75 \%$ dintre angajații lor. Pe o rută distinctă, suport financiar din surse publice se acordă și altor forme ale relațiilor de muncă (PFA, drepturi de autor, asociație familială, angajați ai unor forme cooperatiste) cărora le este afectată activitatea în urma restrictiilor aduse de starea de urgență.

Dacă în cazul primilor nivelul venitului protejat este de $75 \%$ din salariul anterior brut (de bază), fără a depăși $75 \%$ din salariul mediu brut pe economie (5 243 RON, în februarie 2020), în cazul ultimilor este vorba despre o indemnizație lunară echivalentă cu salariul minim brut pe țară (2 $230 \mathrm{RON})$. În cazul primilor, cuantumuri peste pragul maxim, ca și prevederi pentru cuantumuri mai mari eventual prevăzute în contractele colective de muncă pot fi, respectiv trebuie asigurate de către angajator. În absența unor estimații cu privire la aceste din urmă situații, să observăm că măsura dezavantajează puțin peste un sfert dintre contractele cu normă întreagă (Tabelul $n r$. 3). În același timp, lipsesc și estimări privind situațiile în care au fost suspendate bonus-urile (ex.: tichete de masă, diverse sporuri) sau s-a acceptat măsura unui număr de zile/ lună de concediu fără plată, ca modalităţi alternative de reducere a costurilor cu forta de muncă.

La prima vedere în dezavantaj, în cazul altor forme de asigurare alocatia de suport protejează prin menținerea (integrală) a veniturilor asigurate a cca. $90 \%$ din cei aflați în astfel de situații. Dezavantajul se conturează pentru contractele cu fracție de normă față de formele alternative, prin faptul că, la un venit asigurat la nivelul salariului minim, venitul protejat prin alocație este mai mic datorită formei contractuale. Ponderea contractelor part-time este redusă comparativ cu statele europene dezvoltate (Ilie și Preoteasa, 2017). În plus, suspectate a incumba plată informală a muncii, o scurtă perioadă (2018) regimul lor de impozitare a fost la nivelul unei norme întregi de muncă, ceea ce a demotivat apelul la astfel de 
contracte. Se atestă astfel lipsa de receptivitate a economiei și politicii sociale românești la flexibilizarea pieței muncii prin contractele cu fracție de normă; acestea pot atrage pe piața formală a muncii categorii în risc de excluziune, care nu pot răspunde cerințelor de timp ale unei norme standard de muncă.

Nivelul veniturilor asigurate dobândește o importanță deosebită în contextul prezentei crize, aducând în atenție ocuparea nesalarială și economia informală, care pot atinge cote mari în ocuparea unei regiuni (Tabelul nr. 1). Chiar și în contextul economic favorabil al anului 2008 , cca $11 \%$ din populația ocupată de peste 15 ani avea venituri doar din activități informale, alături de alte cca $23 \%$ persoane ocupate doar în activitatea gospodăriei, care păstrau pentru consumul propriu mai mult de jumătate din producția astfel rezultată. Mediul rural era cu deosebire expus, 68\% din populația ocupată având doar astfel de venituri (Stănculescu, Marin, Hommes, 2009). Studiul amintit ia în considerare şi membrii familiei care munceau în străinătate, rămași în contact apropiat cu gospodăria din România, către care trimiteau bani, sume în creștere după 2013 (Eurostat, bop_rem6).

Indiferent de locul prestării lor, actualul context a diminuat oportunitățile formale și informale de muncă și deci resursele monetare ale gospodăriilor. Simultan, gospodăria putea să se fi extins, prin revenirea în țară a celor care munceau în străinătate. În absența unor oportunități de muncă populația de vârstă activă poate apela la beneficii sociale, în prezent la niveluri foarte scăzute. Anunțatele măsuri dedicate susținerii ocupării ulterior ridicării restricțiilor se dovedesc absolut necesare. Între acestea susținerea recalificării, plata de către stat a unei părți a salariului în cazul menținerii în activitate sau al angajării celor cărora le încetează şomajul tehnic, ca și a celor care provin din grupuri vulnerabile (au între 16 și 29 sau peste 50 de ani), respectiv au revenit în țară prin încetarea contractelor în străinătate ${ }^{7}$.

Atât reglementarea cu privire la șomajul tehnic cât și alte măsuri de suport social s-au modificat în raport cu primele lor forme în decursul stării de urgență, în sensul relaxării unora dintre condițiile lor (OUG 30, OUG 32, OUG 53 din 2020). Alte măsuri de protecție a ocupării și veniturilor au fost:

- zile libere pentru părinții care au în îngrijire copii sub 12 ani (sub 18 ani, în cazul celor cu dizabilități sau adulți cu handicap înscriși la unități de învățământ/ centre de zi), și pe durata vacanței școlare, dacă nu este posibilă munca la domiciliu sau telemunca, urmare a închiderii temporare a unităților la care sunt înscriși. Alocația se acordă doar unuia dintre părinţii copilului în îngrijire (dacă celălalt părinte nu este în situația de a putea îngriji copilul), în cuantum similar șomajului tehnic (proporțional cu numărul zilelor libere/ lună). Prevederea este obligatorie la cererea angajatului, exceptând situațiile în care părintele este salariat într-un domeniu esențial, caz în care este necesar acordul angajatorului, după epuizarea altor soluții de flexibilizare a programului de lucru, care să permită continuarea activității (L19/2020).

\footnotetext{
${ }^{7} \mathrm{http}: / /$ mmuncii.ro/j33/index.php/ro/comunicare/comunicate-de-presa/5970-2020-05-29-sarscov-2_cp-guvern-masuri-active.
} 
- Reglementarea unor modificări cu privire la condițiile de creditare, în particular posibilitatea amânării creditelor bancare pentru o perioadă de până la 9 luni (OUG 37/2020). În primele două luni de la instaurarea stării de urgență fuseseră soluționate $83 \%{ }^{8}$ din cererile pentru suspendarea obligațiilor lunare de plată ale celor 304000 persoane fizice și 14 mii persoane juridice (adică 20\%, respectiv $14 \%$ din totalul numărului de credite acordate), în baza reglementărilor Ordonanței, ca și a măsurilor proactive ale băncilor.

- Un stimulent de risc pentru personalul medical direct implicat în controlul stării de sănătate a populației infectate ( $2500 \mathrm{RON}$ brut, lunar, pentru cca. 75000 medici, asistenți medicali, personal care deservește ambulanțele, personal paramedical care lucrează în spitale sau serviciul SMURD). Prevăzut a fi acordat pentru situațiile confirmate a contactului cu persoane infectate, aceasta a fost extinsă în cazul serviciului de ambulanță pentru întreaga lună martie, când serviciul a funcționat pentru toate solicitările, fără a fi fost posibilă testarea pe scară la fel de largă.

- Posibilitatea amânării obligațiilor de plată la utilități și chirie pentru servicii juridice care nu și-au întrerupt activitatea pe timpul stării de urgență - avocaţi, notari publici și executori judecătorești, dacă activitatea ultimei luni a scăzut cu cel puțin 25\% față de media ultimelor 6 luni, dacă activează în forme de organizare cu maxim nouă angajați și venitul net al anului 2019 nu depășește un anumit plafon (HG281/2020).

- Izolarea la locul de muncă (14 zile consecutive) a personalului din centrele rezidențiale de îngrijire (copii și adulți, cu și fără dizabilități), având în vedere vulnerabilitatea și/sau potențialul ridicat de contagiune a beneficiarilor acestor centre. Intempestivă, măsura a ocazionat proteste din partea angajaților, atrăgând atenția asupra dotării deficitare din multe astfel de instituții.

- Utilizarea mai flexibilă a tichetelor gratuite de călătorie acordate persoanelor cu handicap și însoțitorului lor (ordinea utilizării tichetelor, acte de identificare).

- Prelungirea automată a unor drepturi bănești deja în plată (ex.: indemnizația de creștere a copilului, stimulentul de inserție, drepturi ale pensionarilor de invaliditate), dacă eligibilitatea pentru acestea expira în perioada stării de urgență, ca și plata la zi (și nu la revenirea în activitate) aferentă concediilor postnatale.

- Acceptarea cererilor pentru beneficii sociale obișnuite depuse online sau prin poștă (OUG30/2020), ca răspuns la riscul epidemiologic.

- Posibilitatea angajării fără concurs în domenii precum cel sanitar sau apărare.

Companiilor le-au fost destinate împrumuturi; în cadrul Programului de susținere a Întreprinderilor Mici şi Mijlocii, IMM INVEST ROMÂNIA (OUG29/2020) s-au prevăzut credite pentru investiții și capital de lucru, pe maxim 10 ani, garantate maxim $80-90 \%$, în relație inversă cu dimensiunea întreprinderii. De asemenea, a fost plafonat prețul utilităților și al carburanților la nivelul sfârșitului lunii martie (OM4/2020).

\footnotetext{
${ }^{8}$ Răspunsul băncii este în 15 zile, iar un plan de rambursare a sumelor datorate se formulează în 30 de zile. https://www.arb.ro/categorie/comunicate-de-presa/ (accesat 28.04 și 19.05 2020).
} 
Pe de altă parte, unele propuneri nu s-au materializat:

- La începutul lunii aprilie un proiect de lege prevedea posibilitatea amânării plății aferente contribuțiilor sociale pentru persoane fizice și juridice, afectate de măsurile stării de urgență (pentru cei care au suferit reducerea cu cel puțin 15\% a veniturilor față de primele două luni ale anului). Se prevedea, de asemenea, amânarea plății chiriilor și a utilităților, inclusiv cablu-TV și internet, pe trei luni, cu eșalonarea datoriei pe 12 luni, fără dobândă sau penalități. Companiile furnizoare urmau a fi susținute din credite fără dobândă pe maxim 12 luni, iar Guvernul urma a defini până la 1 mai, consumatorul vulnerabil. Contestată ca măsură populistă, ca insuficient de clar definiți cei în nevoie sau propusă prea devreme ${ }^{9}$, reglementarea a dobândit o nouă formă la sfârșitul lunii aprilie ${ }^{10}$. Accentul acesteia din urmă cade pe plata chiriei, inclusiv pentru luna următoare încetării stării de urgență (în limita a $410 €$ euro pentru persoane fizice, $2000 €$ persoane juridice), posibil de amânat până la sfârșitul anului, dar necesită încă o serie de clarificări. Locatorul ar urma să beneficieze de o reducere a impozitului aferent acestor venituri pentru reducerea cu cel puțin $30 \%$ a chiriei convenite.

- Aflată pe agenda publică la începutul anului, respinsă ca neconstituțională, dar reiterată în contextul crizei, propunerea de impozitare a pensiilor mari nu avea o formă cristalizată la sfârșitul lunii mai ${ }^{11}$.

- În prima parte a lunii aprilie, voci ale Administrației Centrale prefigurau tăieri salariale pentru instituțiile bugetare, exceptându-i explicit, legitim, pe cei din domenii direct solicitate în această perioadă, dar referindu-se explicit și la demnitari. $\mathrm{O}$ astfel de măsură nu a surprins, în condițiile experienței crizei trecute, a efortului financiar presupus de plata șomajului tehnic și a creșterii drepturilor salariale în ultimii ani pentru o parte a forței de muncă din sectorul public. Ea se anunța mai prompt decât în urmă cu un deceniu (și nu la un an distanță de la debutul crizei), cu niveluri similare ale reducerii (20-25\%), dar fără specificații legat de durata reducerii, dacă acestea sunt restituibile sau nu, sau de modul în care aceste reduceri se combinau cu șomajul tehnic, incident și în sectorul public. De asemenea diferit, argumentarea măsurii nu se plasa în zona echilibrului bugetar (deși acesta a rămas valabil), ci în apelul la solidaritate, rezonant cu considerentele de sănătate publică și siguranță națională ca motivatori ai restricțiilor prezentului context. Până la începutul lunii mai, ideea unei astfel de măsuri părea să fi fost abandonată.

\footnotetext{
${ }^{9}$ https://republica.ro/legea-pentru-acordarea-unor-facilitati-fiscale-contribuabililor-persoanefizice-si-juridice-este-populista; https://m.hotnews.ro/stire/23782881; https://www.enpg.ro/wp-conte nt/uploads/2020/04/EPG_Amanarea-platii-utilitatilor_Analiza_5-aprilie_final.pdf (accesat 2.05.2020).

${ }^{10} \mathrm{Ce}$ facilități la plata chiriei au fost adoptate?, Filip and Company, 1.05.2020 https://www. lexology.com/library/detail.aspx?g=43a8e646-0f5c-4479-a0b5-d21a049086db.

${ }^{11}$ Cât de speciale sunt pensiile privilegiaților și cum le-au obținut, Rădulescu A., 7.01 2020, „Jocul populist" cu pensiile speciale. Cum poate bloca un articol din Constituție impozitarea pensiilor speciale cu 90\%, Andrei C. 22.05.2020 https://romania.europalibera.org/a (accesat 28.05.2020).
} 
Între timp au avut loc majorări salariale, conform planificării din 2017, pentru câteva categorii ocupaţionale salarizate în baza legii salarizării bugetare, dar sunt semne de întrebare în legătură cu posibilitatea majorării pensiilor de asigurări sociale prevăzută pentru toamna acestui an, conform programării.

\section{Protecția ocupării și veniturilor în contextul COVID-19: practici internaționale}

Analiza comparativă a măsurilor dedicate susţinerii ocupării și protecției veniturilor populației în contextul pandemic COVID-19 (vezi Anexa 2-4) a vizat țări cu abordări diferite ale pieței muncii, determinante în mare parte pentru modelul lor social. Succint, caracteristicile țărilor observate sunt:

- Germania și Franța (modelul continental, centrat pe beneficii asigurate, dependente de participarea pe piața muncii);

- Suedia (modelul nordic, cu intervenție extinsă prin măsuri active, beneficii universale bazate pe principiul cetățeniei, nivel redus al inegalității distribuției veniturilor);

- Marea Britanie (modelul anglo-saxon, cu inegalități accentuate de venit, protecție prin intervenție asistențială, mai degrabă protecție prin beneficii de șomaj decât prin politici de ocupare, cu cea mai ridicată prezență a salariaților cu salarii mici în totalul salariaților, între modelele în discuție) și

- Spania (modelul mediteraneean, cu prezență relativ redusă a beneficiilor de tip asistențial, protecție accentuată a ocupării, inegalitatea veniturilor, risc și severitate a sărăciei mai ridicate comparativ cu modelele anterior menționate).

- În România regăsim contribuția minimă a intervenției asistenţiale în combaterea sărăciei, ponderi între cele mai mari ale salariaților cu salarii mici în total salariați, inegalităţi accentuate de venit pre- și post-transferurii sociale, ca şi o pondere de 2-3 ori mai extinsă a ocupării nesalariale în total ocupare 18-64 ani prin comparație cu țările spațiului european (Esping-Andersen, 1999; Boeri, 2002; Ilie, 2017).

Chiar în contextele diferite ale primelor patru modele, se conturează unele comunalități ale intervenției. Direcția principală de suport a fost evitarea disponibilizării forței de muncă. Referința în această directie este modelul german al alocației pentru reducerea timpului de muncă $\left(T_{R M}{ }^{12}\right)$, cu primele astfel de măsuri mai vechi de un secol. Măsura se adresează angajatorului, pentru a-l motiva să-și păstreze angajații în situații în care, pe termen scurt, trebuie să reducă timpul contractual de muncă. Eligibilitatea firmei pentru astfel de alocații acoperă și situații de necesitate (cum este prezentul context), dar mai ales situații în care

${ }^{12}$ TRM este acronimul folosit în această lucrare pentru măsura alocațiilor subvenționate de stat (integral sau pațial) în diferite țări. Acestea sunt Kurtzarbeit (Germania), short-time work (Marea Britanie), allocation d'activité partielle (Franța); ERTE expediente de regulación temporal de empleo (Spania). 
reducerea este generată de condiții economice dificile, nevoia de retehnologizare, reprofilare, modernizare sau renovări capitale. Condiții similare există și în Franța și - într-o astfel de abordare - este evident scopul protejării parteneriatului profesional angajat - angajator; este în interesul tuturor (inclusiv al statului) să se mențină contractul, forța de muncă fiind deja adecvat calificată și obișnuită cu specificul organizațional al firmei, ceea ce reduce timpul de productivitate scăzută (necesar adaptării), odată activitatea reluată. În logica reducerii timpului slab productiv, cheltuieli pentru actualizarea calificării forței de muncă eventual necesară după repornire pot fi decontate de stat.

Alocația se plătește angajatorului și urmează ca acesta să o transfere angajatului. Nivelul alocației acoperă salariul anterior în proporții diferite: $66,6 \%$ în Portugalia, $70 \%$ în Belgia și Franța sau $100 \%$ în Olanda și Norvegia din salariul brut, respectiv între 60-67\% Germania și 100\% Irlanda din cel net. Alocația se acordă pe durate variate (3-12 luni), cu posibilitatea unei extinderi sau a reaplicării (dar limitat). În general nivelul alocației variază invers cu durata acordării sale, dar asigură venituri superioare celor care s-ar primi prin ajutorul de șomaj obișnuit (Schulten și Müller, 2020).

Republica Cehă, Slovacia, Ungaria, Polonia sau Olanda au introdus astfel de măsuri în contextul crizei financiare de acum un deceniu (Hijzen și Venn, 2011), iar mai recent și Suedia și Marea Britanie. Extinderea modelului în mai multe țări, cu particularități naționale diferite, a ocazionat analize care au pus în evidență și dezavantaje ale sale, precum faptul că nu se adresează și celor cu contracte temporare, că poate demotiva căutarea unui loc de muncă și relocarea forței de muncă în domenii mai productive, nu funcţionează ca un reglator adecvat al reducerii volumului de ore necesar de redus, inclusiv în situații de criză, atât timp cât decizia și nivelul reducerii necesită acordul unei largi părţi a salariaţilor, sindicalizați sau nu (Cahuc, 2019).

Pe de altă parte, variatele diferențe naționale în ce privește eligibilitatea angajaților, a firmelor, durata de acordare, contribuția efectivă a statului în asigurarea alocației şi chiar denumirea alocaţiei estompează caracterul intenționat al măsurii, de protecție activă a forței de muncă; de altfel relaxările suferite în contexte de criză, accentuează rolul de protejare a veniturilor populației, plasând secundar caracterul de măsură activă. Ajustările observate în prezentul context se pot rezuma astfel:

- A fost coborât pragul minim al gradului de reducere a activităţii, care califică angajatorul pentru alocație, ceea ce înseamnă un suport mai generos al statului, din faze mai puțin severe de necesitate.

- S-a renunțat la cerința unei durate minime pre-existente a contractului sau s-a extins eligibilitatea și asupra contractelor part-time, sezoniere, iar în Franța și asupra muncii în servicii domestice. Prin acoperirea ocupării atipice s-a depășit una dintre criticile aduse de obicei acestui tip de intervenție. 
- În logica utilizării sale pe termen scurt este firească menținerea obligativităţii plății contribuțiilor social-fiscale, dar și a beneficiilor sociale la care angajatul are dreptul (după criterii obișnuite de eligibilitate). Ca prevedere adaptată, plata contribuțiilor sociale a fost amânată fără penalizări. Germania a prevăzut explicit creșterea limitei câștigurilor complementare drepturilor de pensie anticipată, care nu atrag diminuarea pensiei primite. Pe de-o parte, se oferă astfel o soluție pentru menținerea bunăstării populației, diferența de venit complementar putând acoperi diminuarea veniturilor unui alt membru al familiei. Pe de alta, se deschide astfel calea spre reîncadrarea (temporară) celor cu drepturi de pensie anticipată, o posibilă soluție la deficitul de personal din activități care au resimțit sever criza.

- Munca independentă este tratată fie ca situație particulară a persoanei fizice, fiind abordată din perspectiva protecției veniturilor populației, fie ca situație particulară a unei micro-întreprinderi. În primul caz sunt relaxate condiţiile pentru calificare la beneficii (se suspendă obligativitatea contribuției minime preexistente/ se majorează pragul de venit în funcție de care se calculează beneficiile pentru care sunt eligibili/ se amână termenul evaluării contabile a activității pentru actualizarea sarcinilor de plată). În al doilea caz se prevăd relaxări la plata chiriilor și a utilităților, reducerea impozitelor datorate pentru salariații cu salarii sub un anumit nivel (pentru firme cu mai puțin de 30 de angajați: Suedia), ca și acordarea de microcredite sau credite cu dobândă redusă pentru susținerea activității.

- Există limitare maximală a salariilor pentru care statul suportă alocația, respectiv ajutorul statului se diminuează în relație cu gradul de afectare a activității sau dimensiunea firmei; sunt și prevederi explicite privind exceptarea de la facilități a firmelor cu stabilitate financiară sau din rândul instituțiilor publice, după cum Germania a luat în considerare și majorarea impozitării mai accentuate a veniturilor mari.

- O condiție larg prezentă pentru acordarea de sprijin este ca angajatorul/ micul antreprenor beneficiar să nu fi avut datorii la plata sarcinilor social-fiscale sau să nu se afle în situație de executare silită la momentul declarării stării de urgență. Se recompensează astfel comportamentul fiscal corect.

Între măsurile pentru protecția veniturilor populației se numără și relaxarea criteriilor pentru acordarea ajutorului de șomaj, tichete de consum (ulterior încetării stării de urgență), includerea în cheltuielile deductibile a celor profesionale ocazionate de relocarea muncii la domiciliu (Germania), dar clar conturate au fost prevederile pentru înțelegeri între proprietarii proprietăților imobiliare și chiriași privind amânarea plății chiriilor și reeșalonarea și/sau reducerea cuantumului acestora. Cele mai categorice reglementări în acest sens prevăd interdicția penalizării/ evacuării pentru neplata chiriei (sau a creditelor ipotecare) timp de trei 3 luni (inclusiv a celor care aveau deja datorii; Marea Britanie), ca și prevederea explicită pentru locatorii cu mai mult de două proprietăți închiriate de reducere a chiriilor cu $50 \%$ (Spania). 
Sprijinul pentru companii este completat prin împrumuturi garantate de stat pentru capital de lucru, amânări sau reeșalonări ale unor datorii de plată curente (impozite, contribuții sociale, TVA), reducerea cotei de TVA, dar și a altor tipuri de impozite, în vederea stimulării investițiilor și dezvoltării, ca și susținerea investiţiilor publice (de infrastructură).

Se conturează, de asemenea, un sistem administrativ informatizat, integrat cu capacitate sporită de răspuns, partener al mediului privat, care să permită sprijinul rapid. Astfel, majoritatea solicitărilor sunt bazate pe dialogul instituțional online, pe declarația pe proprie răspundere cu specificarea particularității contextului COVID-19 asociat situației de necesitate, urmând ca verificarea/ regularizarea/ corectarea eventualelor erori de incluziune să se realizeze ulterior (prin documente contabile, medicale), alături de suplimentarea personalului care preia solicitările, creșterea perioadei în care se pot depune cereri pentru solicitarea ajutorului. Cazul Franței, unde termenul de răspuns al autorităţilor este de 15 zile, dincolo de care cererea se consideră tacit acceptată, respectiv reducerea acestui termen la două zile în condiții de criză vorbește de la sine în acest sens.

Desigur, fiecare țară modelează intervenția în criză în funcție de contextul propriu, păstrând însă coerența ideologică a politicii sale sociale. Î̉n spațiul public se fac frecvente referiri la stabilitatea și puterea economică a Germaniei sau la universalitatea suportului social al țărilor nordice, omițându-se uneori larga asimilare în aceste societăţi a valorilor solidarităţii și echităţii sociale. $\mathrm{Nu}$ surprinde, astfel, intervenția diferențiată a statului în susținerea companiilor, păstrând o cotă în sarcina angajatorului în cazul Suediei (singulară în această situație). Tot astfel, nu surprind așteptări mai mari ale Germaniei din partea celor cu venituri mari (fie prin considerarea unei impozitări suplimentare în partea superioară a distribuției veniturilor populației, fie prin protestul comunităţii și susținere din partea autorităţilor față de decizia unor companii multinaționale de a refuza plata chiriei pentru spațiile utilizate pe perioada restricționării activității, pledându-se pentru înțelegeri între părți privind reducerea chiriilor datorate).

România are o inegalitate a veniturilor populației ceva mai mare decât a Marii Britanii (Eurostat, tessi190), dar o intervenţie mai indecisă pentru susținerea celor cu venituri mici. Poate cea mai clar conturată diferență între România și țările observate apare în relație cu protecția ocupării pe cont propriu și a microîntreprinderilor, pentru suport în vederea plăţii chiriilor pentru spațiile utilizate, a utilităților sau a cheltuielilor profesionale majorate în contextul translatării muncii în spațiul personal. Nonprotecția populației la plata chiriilor, poate fi înțeleasă prin ponderea redusă a chiriașilor în totalul gospodăriilor românești și promptitudinea reglementării suportului pentru credite. Profilul ocupării românești pe cont propriu, înalt vulnerabil și atipic în spațiul european (Ilie și Preoteasa, 2017) este însă, în sine, justificativ pentru ca susținerea în direcția suportului faţă de orice formă mic-antreprenorială să fie promptă, privind toate aspectele care îi pot susţine dezvoltarea. 


\section{O PERSPECTIVĂ CONCLUZIVĂ: INEGALITĂȚI ȘI SCHIMBARE}

Prezenta pandemie se datorează extinderii unui virus pentru care, pe moment, nu există tratament specific. Mai ales în aceste condiții, creșterea accelerată a îmbolnăvirilor prezintă riscul depășirii capacității de răspuns a sistemului de sănătate. Statele lumii au tins să considere prioritară protejarea sănătății publice, asumându-și costuri economice imediate, prin restricționarea unor activității. Simultan, au fost formulate măsuri privind protecția ocupării, a veniturilor, dar și măsuri de suport care adresează momentul depășirii crizei.

Măsurile restrictive, impuse şi în România, s-au resimțit neuniform pe ramuri economice, prin natura activității acestea având un grad mai mare sau mai mic de contagiune, respectiv fiindu-le mai mult sau mai putin disponibile opțiuni de ajustare a activității la măsurile preventive. Domeniul hotelier și al alimentației publice, turismul, activitățile cultural-artistice, unele ramuri ale industriei prelucrătoare, construcțiile sau domeniul imobiliar au fost imediat afectate. A existat și o grupă de activități care, implicate în gestionarea sanitară și economică a crizei nu au restrâns semnificativ activitatea, după cum au existat și activități care au găsit în actualul context oportunități de dezvoltare. După o lună și jumătate de la instaurarea stării de urgență, dar mai accentuat după două luni, activitățile economice s-au reluat gradual, ultimele care reiau activitatea fiind chiar primele și cel mai sever restricționate.

Detalierea indicatorilor ocupării românești tinde să contureze risc mai mare de reducere a activitătiii în domenii cu niveluri salariale mai reduse, cu prezență mai scăzută a ocupării salariale, ca și un impact regional inegal. Cel mai mic impact asupra veniturilor și ocupării tinde să se resimtă în regiunea București-Ilfov, aceasta având cel mai favorabil profil al ocupării și cel mai mic risc de săăcie.

Practicile internaționale indică preocuparea statelor europene pentru protejarea veniturilor celor mai vulnerabili, prin extinderea eligibilității sau printr-un minim majorat aferent beneficiilor acordate. Simultan, se conturează așteptarea ca cei mai puțin afectați de criză să contribuie la efortul de depășire a situației de dificultate, prin exceptarea lor de la unele facilități, respectiv formularea de noi sarcini de plată. Ca tendință, obligațiile social-fiscale și de plată s-au menținut, dar s-au amânat sau re-eșalonat, comportamentul fiscal conformant pre-existent fiind o condiţie de eligibilitate pentru facilităţi sau alocații curente. Se profilează, astfel, preocuparea pentru ținerea sub control a inegalitătilor în veniturile populației și totodată pentru controlul raportului (dacă nu chiar echilibrarea) între cheltuieli și venituri bugetare.

Centrală pentru protecția ocupării a fost alocația TRM, o măsură de flexibilizare a pieței muncii, din categoria celor de protecție activă a ocupării. În multe țări pre-existentă acestui moment, măsura permite ajustarea dimensiunii costurilor salariale ale angajatorului la scăderea semnificativă a producției. În condiții de necesitate, cum este și acum cazul, sunt relaxate o serie de condiții de 
eligibilitate. Sensibilitatea măsurii la context este de prim interes, alternativ forța de muncă fiind eligibilă pentru beneficii sociale cu niveluri mai scăzute decât aceasta.

Măsura şomajului tehnic în forma implementată în România în contextul acestei crize este rezonantă cu abordarea TRM din spațiul european. Actuala criză a survenit după câțiva ani de creștere economică, cu tendințe pozitive în ocupare, cu o creștere semnificativă a salariilor la baza distribuției lor, cu o creștere a pensiilor marii majorități a pensionarilor apropiată celei de creștere a PIB, dar și cu accentuarea inegalității veniturilor populației. În contextul general pozitiv al ultimilor ani, beneficiile sociale pentru care sunt eligibile cele peste 400000 persoane cărora le-a încetat contractul de muncă în contextul COVID-19 sau au pierdut oportunitătíle de venituri pe care le aveau (în țară sau în străinătate) au rămas la un nivel foarte scăzut.

În același timp, exceptând limitarea alocaţiei TRM peste un prag salarial, larg prezentă în toate țările observate, între măsurile formulate în spațiul românesc lipsesc aspecte precum: protecția față de creșterea cheltuielilor individuale/ ale gospodăriei odată cu translatarea la domiciliu a activităţii profesionale sau educative, încurajarea efortului individual în menținerea veniturilor, apelul la o contribuție explicită, în formă instituțională (nu caritabilă individuală), din partea celor a căror activitate nu a fost afectată și, în genere, aspecte menite să țină sub control accentuarea inegalității veniturilor. Pentru a tempera creșterea inegalității veniturilor și a riscului de sărăcie pe termen mediu, susținerea ocupării și protecția socială post-criză trebuie să adreseze aceste aspecte, să urmărească o mai bună focalizare a situațiilor de vulnerabilitate, să stimuleze creșterea ocupării formale în regiuni cu risc mai ridicat de sărăcie, să favorizeze consolidarea inițiativei mic-antreprenoriale autohtone și să dobândească coerență și stabilitate în fundamentarea lor ideologică.

Alături de diminuarea veniturilor pentru largi segmente de populație, ca orice criză și aceasta a semnalat oportunități de dezvoltare. O schimbare majoră, incontestabilă, este extinderea comunicării şi afacerilor online. Tendința nu este o surpriză, manifestându-se și anterior crizei. Între aspectele cărora politicile moderne trebuiau să ofere un răspuns, Strategia Europeană de Ocupare 2020 a semnalat tot mai intensa preocupare a indivizilor pentru a echilibra viața de muncă cu cea personal familială, în cadrul perpetuei lor căutări pentru o calitate mai bună a vieții. Evoluția tehnologică, globalizarea și apariția unor noi profesii conturaseră deja munca la distanță drept o formă distinctă, tot mai prezentă, a relațiilor de muncă. Multe țări, și doar de curând și România (L81/2018), au reglementat acest tip de muncă. De-altfel, România este ultima în ierarhia țărilor europene, definită după procentul populației care a recurs la tele-muncă în contextul COVID-19 (cu mai puțin de $20 \%$ din populația ocupată în această situație, față de peste $50 \%$ în țări nordice sau Benelux; Eurofund, 2020). Natura muncii în spațiul național, structura economiei 
pe ramuri de activitate și gradul de răspândire al unor profesii explică în bună măsură aceste diferențe. Extinderea lor ține însă și de gradul în care reglementarea muncii la distanță face față presiunii de extindere. Extinderea și reglementarea nu sunt procese simple, derularea activității în condiţii de tele-muncă necesitând îndeplinirea unor minime cerințe cu privire la: suportul tehnic necesar derulării activităţii (echipamente și infrastructură), securitatea comunicării/ a datelor/secretul profesional, forme de pontaj sau control, împărţirea responsabilității între angajat și angajator privind sănătatea şi securitatea în muncă etc.

Pentru o serie de profesii şi activităţi recursul la telemuncă a fost doar mai extins. Particularitatea, și totodată „meritul”, crizei a fost că a forțat recursul la telemuncă în activităţi atipice (domeniul educaţiei, al justiției, al medicinei, al instituțiilor publice), unde nu exista uzanța relațiilor profesionale la distanță, fie pentru că existau bariere anterior amintite, fie pentru că nu se credea a fi adecvată sau posibilă.

Debirocratizarea relației cu instituțiile publice este un alt potențial câștig al crizei, derivat din primul. Ea a fost semnalată în practica tuturor țărilor observate, fiind motivată de considerentul sănătății publice și nu de cel al aglomerării la sediul instituțiilor (cu care acestea s-au confruntat și în alte conjuncturi). În cazul românesc, amintim practica AJOFM (care făcuse anterior demersuri în acest sens pentru activitatea sa curentă), prin depunerea online a cererilor pentru șomaj tehnic, reducerea numărului de acte solicitate și scurtarea timpului de răspuns din partea instituției. Situații similare s-au regăsit și în practica Casei de pensii publice, a Direcțiilor de asistență socială (cel puțin în faza depunerii cererilor pentru diferite beneficii sociale) sau a Ministerului Economiei, la eliberarea Certificatelor de stare de urgență pentru firme. $\mathrm{O}$ astfel de abordare va simplifica evident relația cu instituția publică, dar va și accentua rolul acesteia de consiliere, parteneriatul cu cetățeanul sau compania, în defavoarea celui birocratic.

În categoria posibilelor efecte pozitive este de amintit stimularea producției interne pentru produse agro-alimentare, mica producție de confecții și echipamente (cu utilizare medicală, dar nu numai), odată ce a fost identificată soluția locală. Ajustarea statisticii privind fenomenul migraţiei externe pentru munca ocazională, ca și dezvoltarea spiritului colaborativ, al solidarității, accentuarea conștiinței comunitare sunt alte aspecte pe care le-am putea găsi la niveluri îmbunătăţite în urma acestei crize.

Desigur, restricțiile stării de urgentă au precipitat aceste practici și, odată cu ridicarea lor, se va reveni în bună măsură la vechile uzanțe, sistemul căutându-și starea de echilibru. Dar, odată ce bariera psihologică sau tehnică a fost depăşită și aceste noi forme de relaționare profesională își vor fi dovedit fezabilitatea, nu se va reveni la locul de muncă și relaționarea profesională așa cum le știam înaintea crizei. Severă pentru o parte a forței de muncă, actuala criză este doar un alt pas spre schimbarea pieței muncii, care se profilează sub presiunea evoluției tehnologice. 


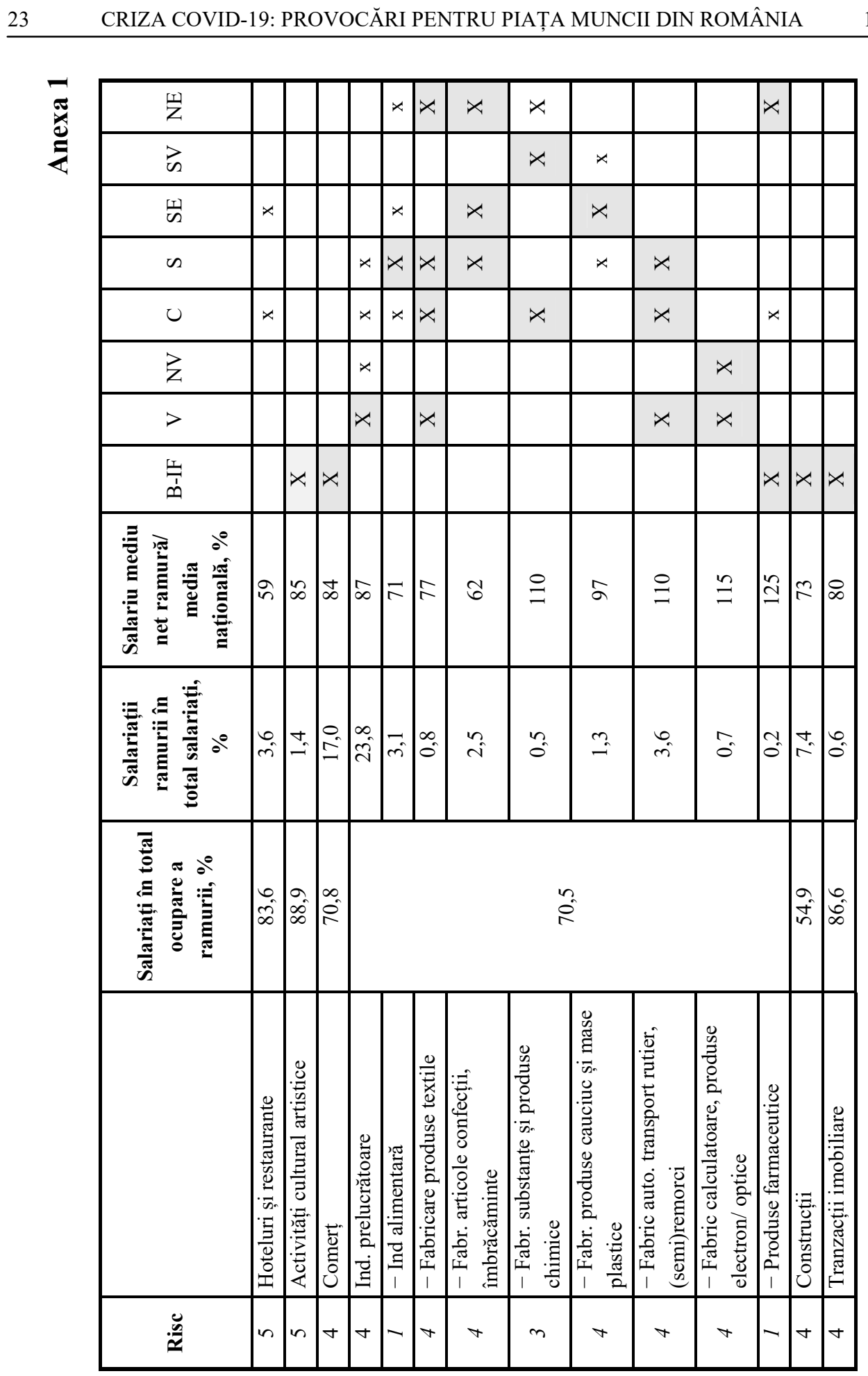




\begin{tabular}{|c|c|c|c|c|c|c|c|c|c|c|c|c|c|}
\hline 罗 & & & & & $x \mid$ & & $x$ & & & $x$ & & $x$ & $\star$ \\
\hline in & & & & & & & $\rtimes$ & & $x$ & $x$ & $x$ & $x$ & \\
\hline$\sqrt[\omega]{\sim}$ & $x$ & & & & & & $x$ & & & $x$ & $x$ & & \\
\hline$n$ & & & & & & & $x$ & & $x$ & $x$ & & $\star x$ & \\
\hline U & & & & & & & & & $x$ & & & & \\
\hline 之 & $\star$ & & & $x$ & 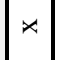 & & & & & & & & \\
\hline$>$ & & & & & $x$ & & $\rtimes$ & & & & & & $x$ \\
\hline$\stackrel{\omega}{\mathscr{n}}$ & & $x$ & $x$ & $x$ & & $x$ & & $x$ & & & & $x$ & \\
\hline 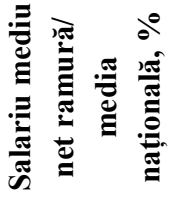 & $\hat{\alpha}$ & 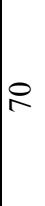 & $\hat{a}$ & $\tilde{\hat{\lambda}}$ & 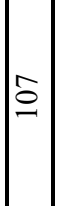 & $\vec{m}$ & $\bar{\infty}$ & $\Xi$ & $\stackrel{\text { fo }}{ \pm}$ & $\underset{\infty}{\ddagger}$ & J & $\hat{\sigma}$ & 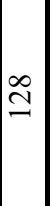 \\
\hline 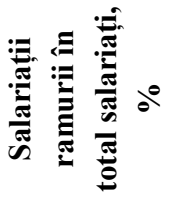 & $\begin{array}{l}0 \\
i n\end{array}$ & $\begin{array}{l}\infty \\
0 \\
0\end{array}$ & 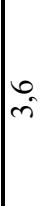 & $\stackrel{\Rightarrow}{\Rightarrow}$ & $\hat{0}$ & $\stackrel{\vec{m}}{m}$ & $\stackrel{\vec{i}}{\mathrm{i}}$ & $\stackrel{\infty}{-}$ & $\because$ & i & $\stackrel{0}{\rightarrow}$ & $\stackrel{0}{+}$ & $\because$ \\
\hline 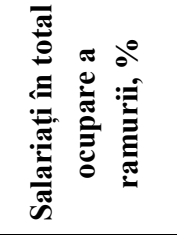 & 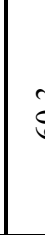 & & & $\begin{array}{l}\infty \\
\infty \\
\infty \\
\infty\end{array}$ & & ஸे & $\stackrel{\circ}{\circ}$ & के & $\begin{array}{l}\infty \\
\hat{\alpha} \\
\hat{a}\end{array}$ & $\hat{n}$ & $\begin{array}{l}0 \\
\hat{a}\end{array}$ & $\begin{array}{l}\infty \\
\mathscr{\sigma}^{\circ}\end{array}$ & $\mid \vec{\infty}$ \\
\hline & 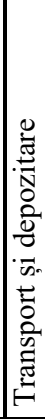 & 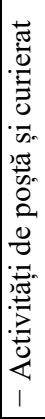 & 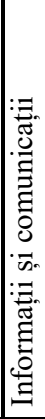 & 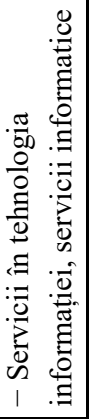 & 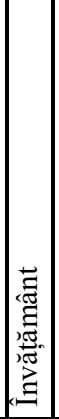 & 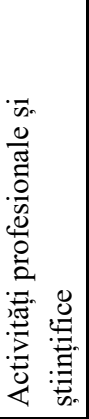 & 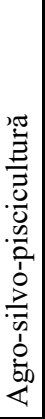 & 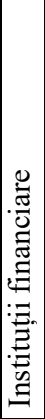 & 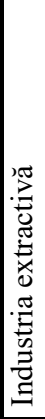 & 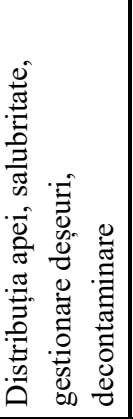 & 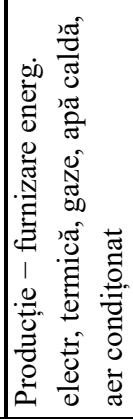 & 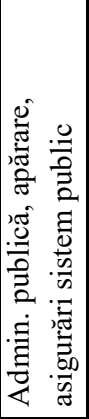 & 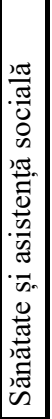 \\
\hline 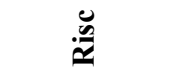 & $m$ & $\sim$ & $m$ & - & $\sim$ & $N$ & $\sim$ & 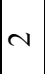 & - & - & - & - & - \\
\hline
\end{tabular}




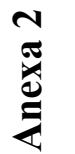

\begin{tabular}{|c|c|c|}
\hline 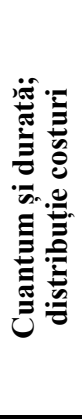 & 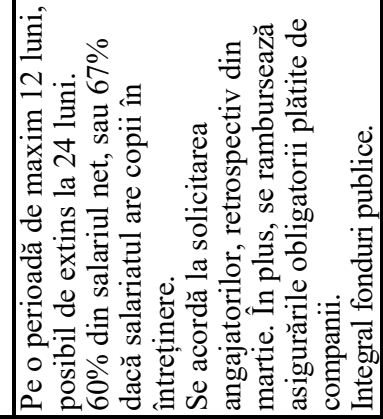 & 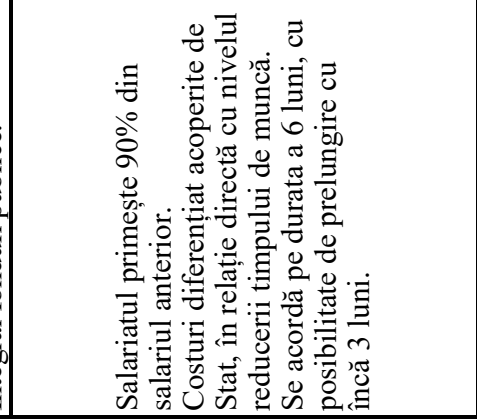 \\
\hline 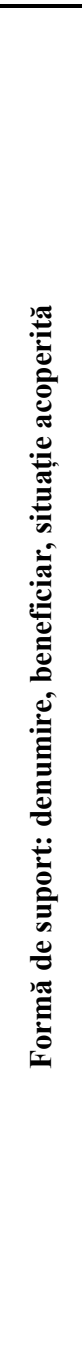 & 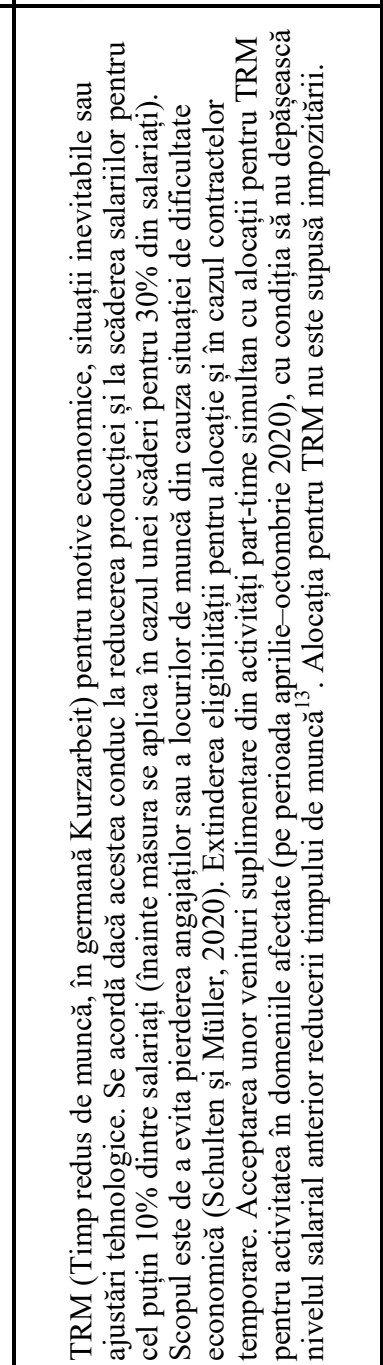 & 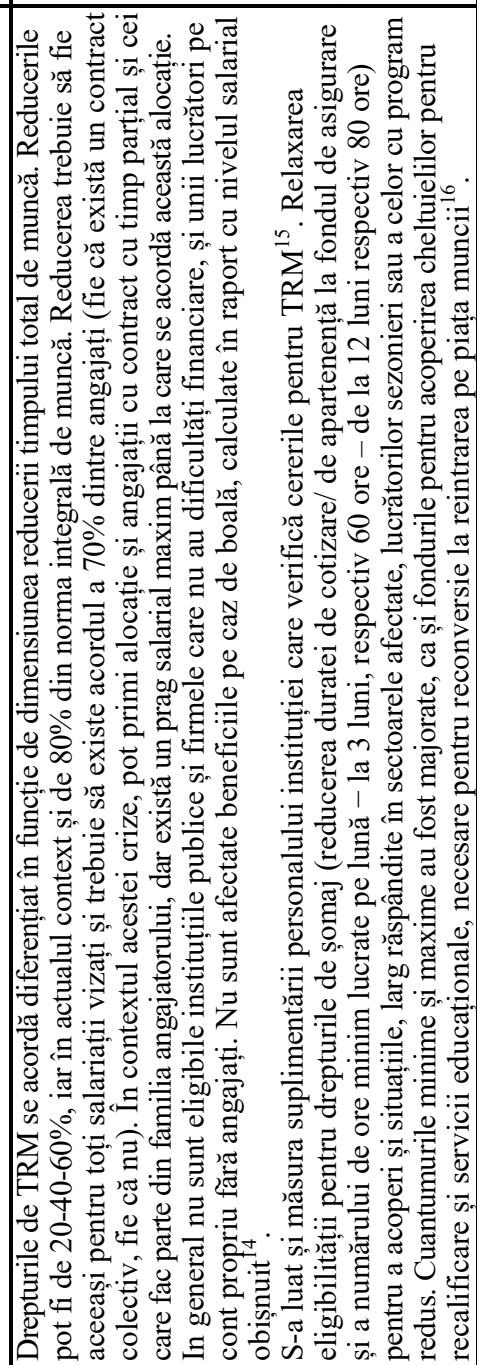 \\
\hline $\bar{F}$ & 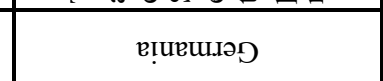 & \\
\hline
\end{tabular}

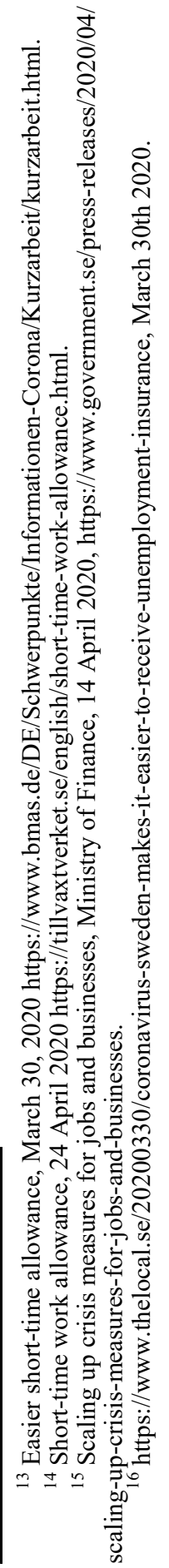




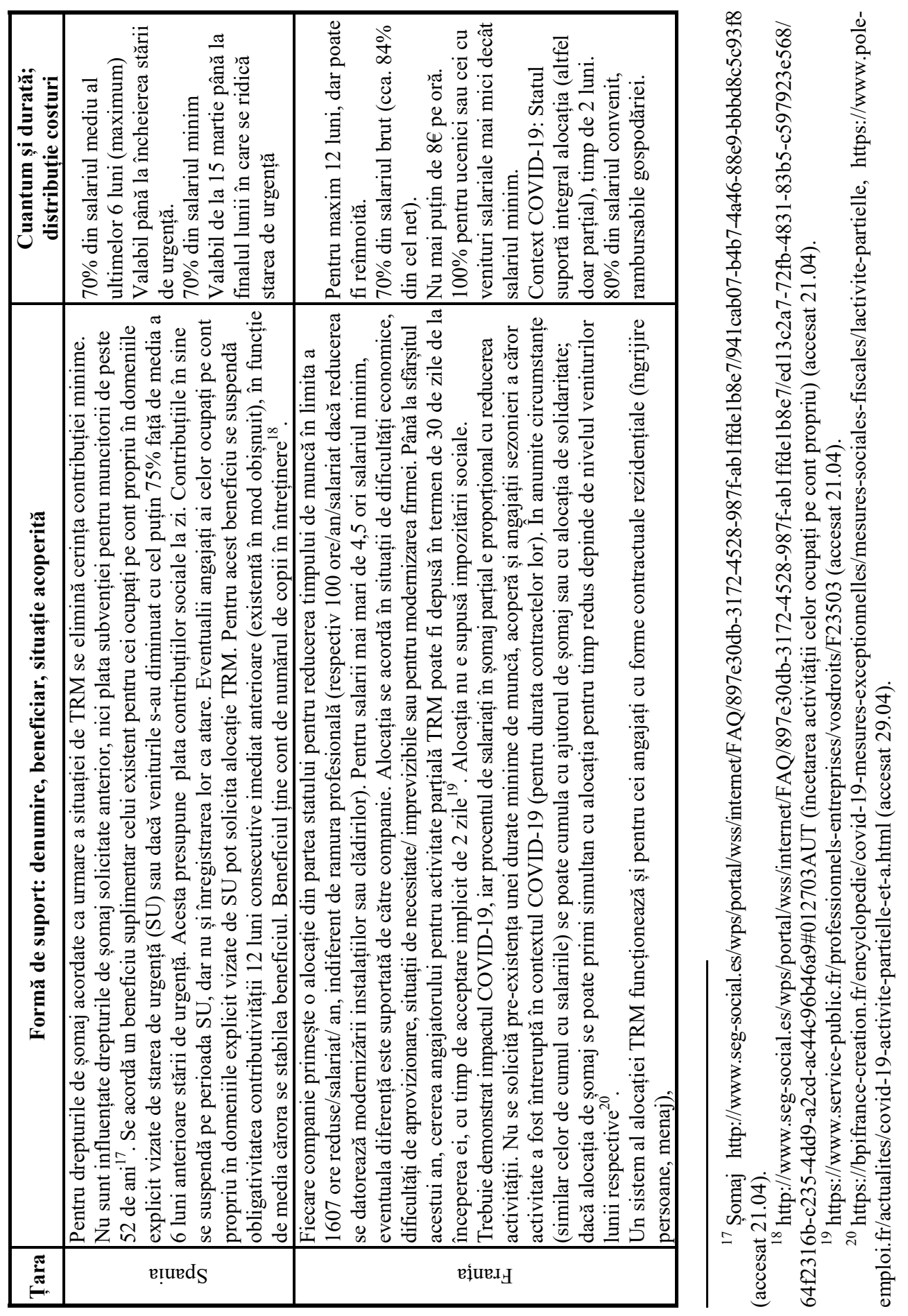




\begin{tabular}{|c|c|}
\hline 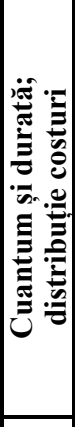 & 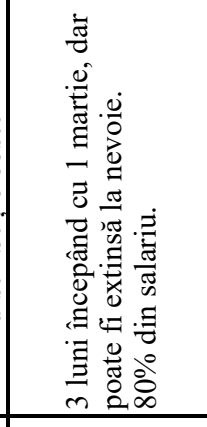 \\
\hline 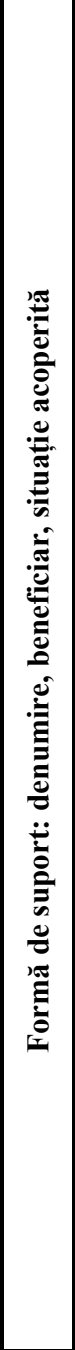 & 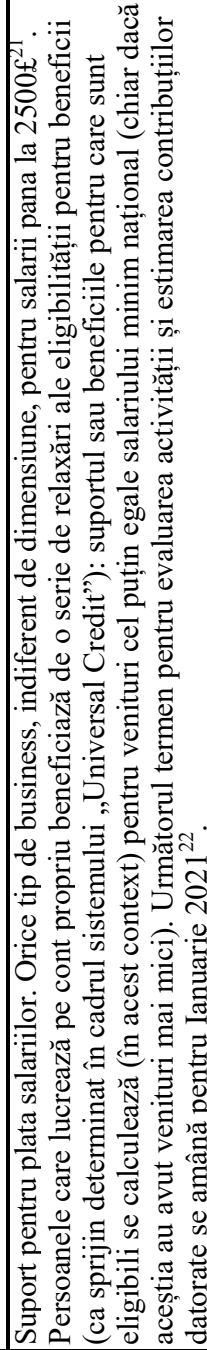 \\
\hline 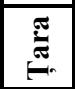 & \\
\hline
\end{tabular}

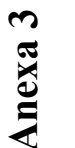

(5)

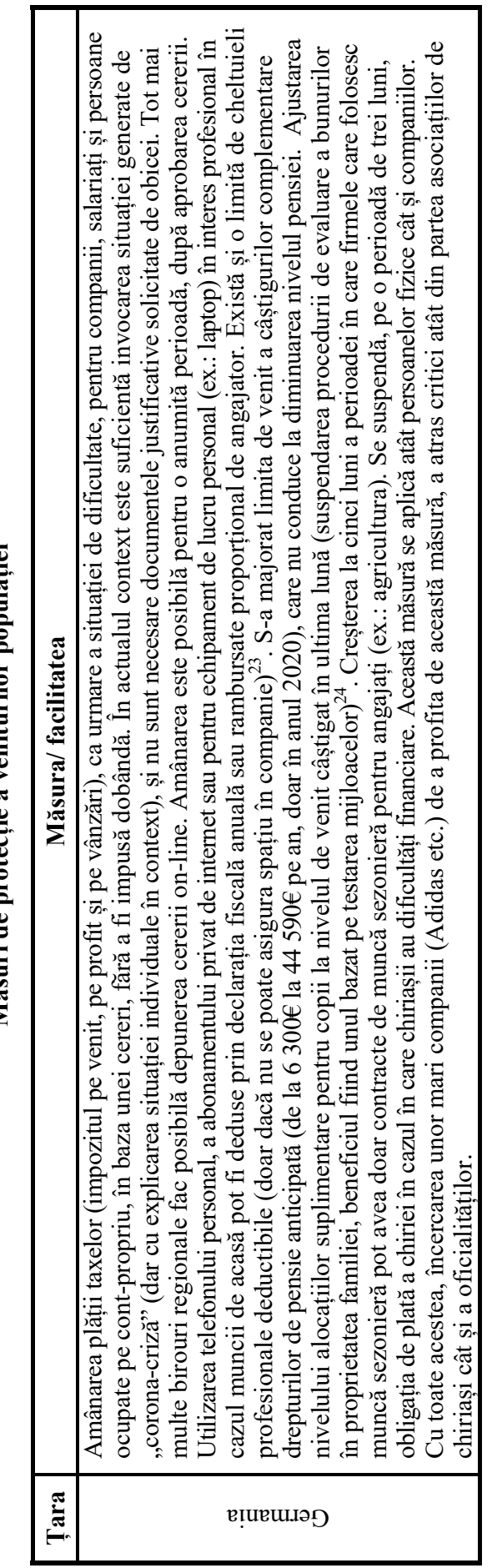




\begin{tabular}{|c|c|c|c|c|}
\hline & 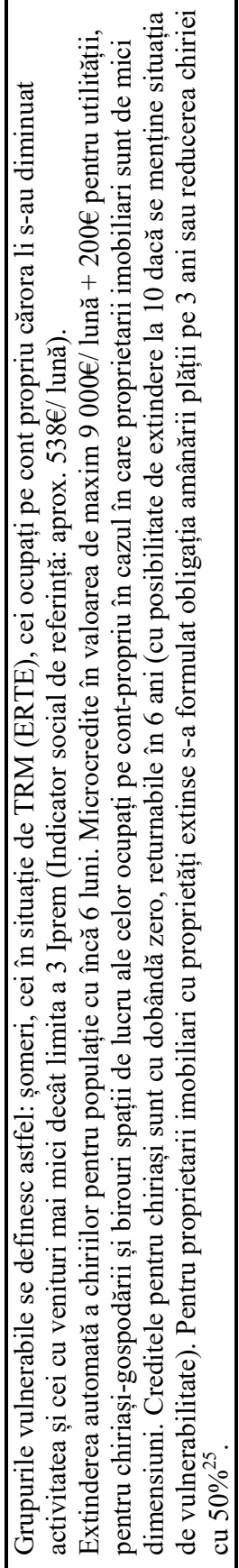 & 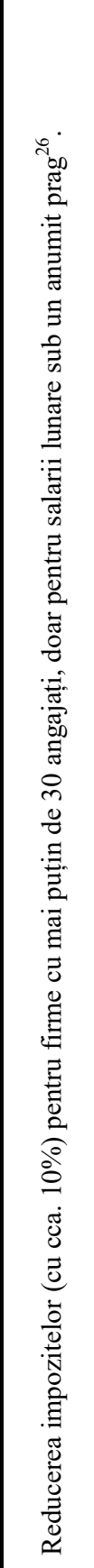 & 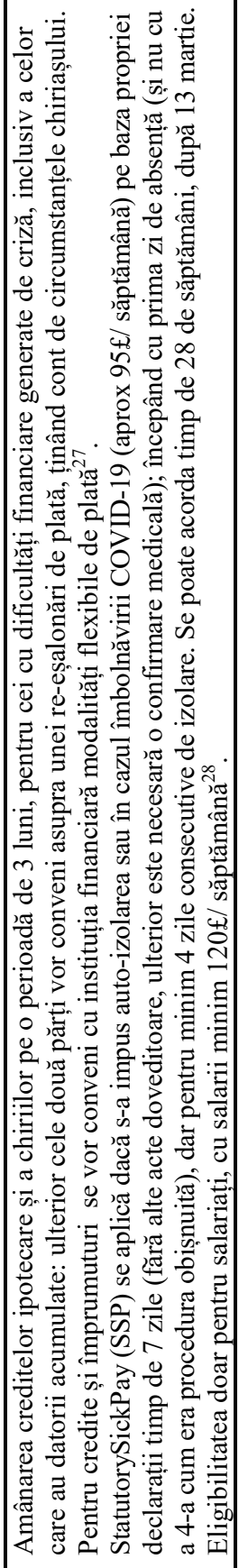 & 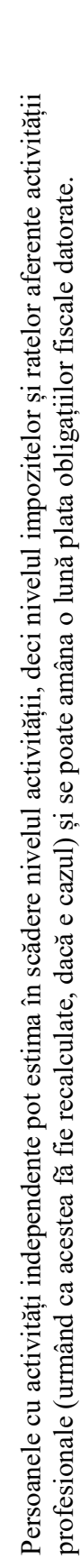 \\
\hline & & oəns & 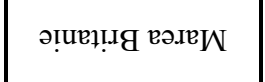 & \\
\hline
\end{tabular}

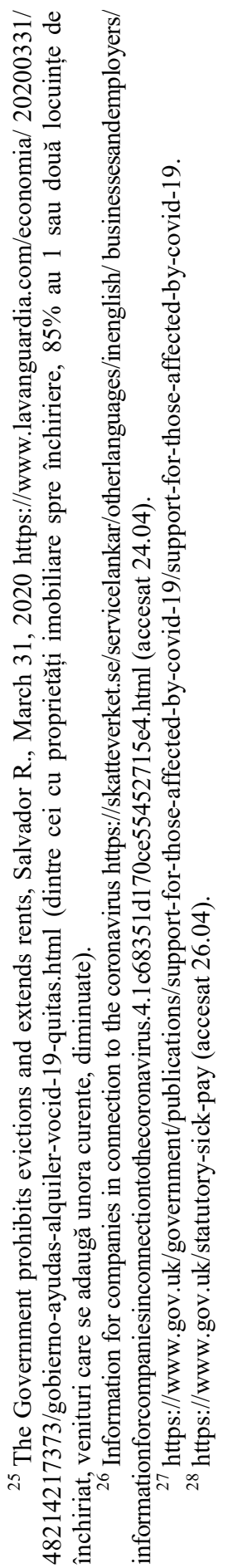




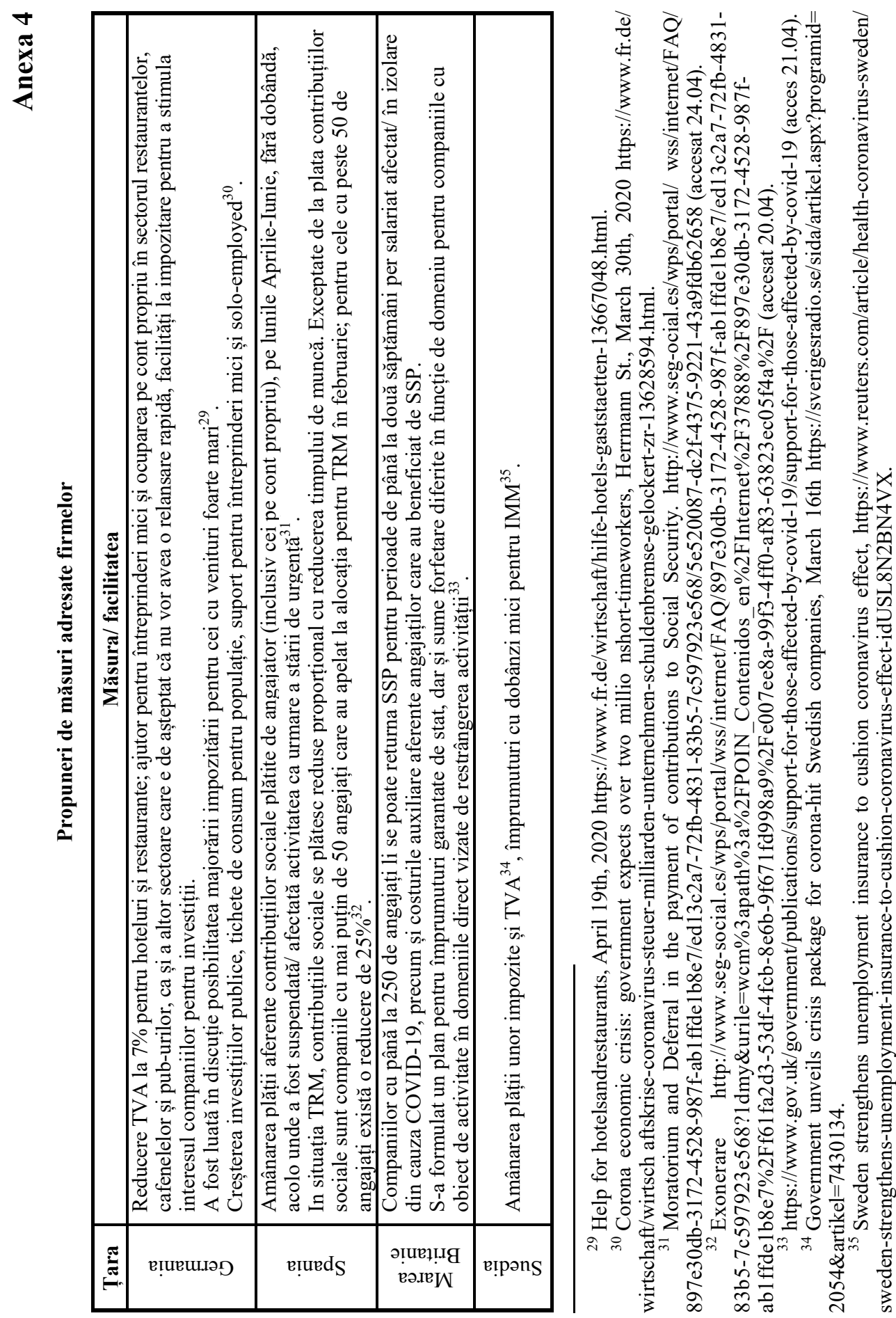



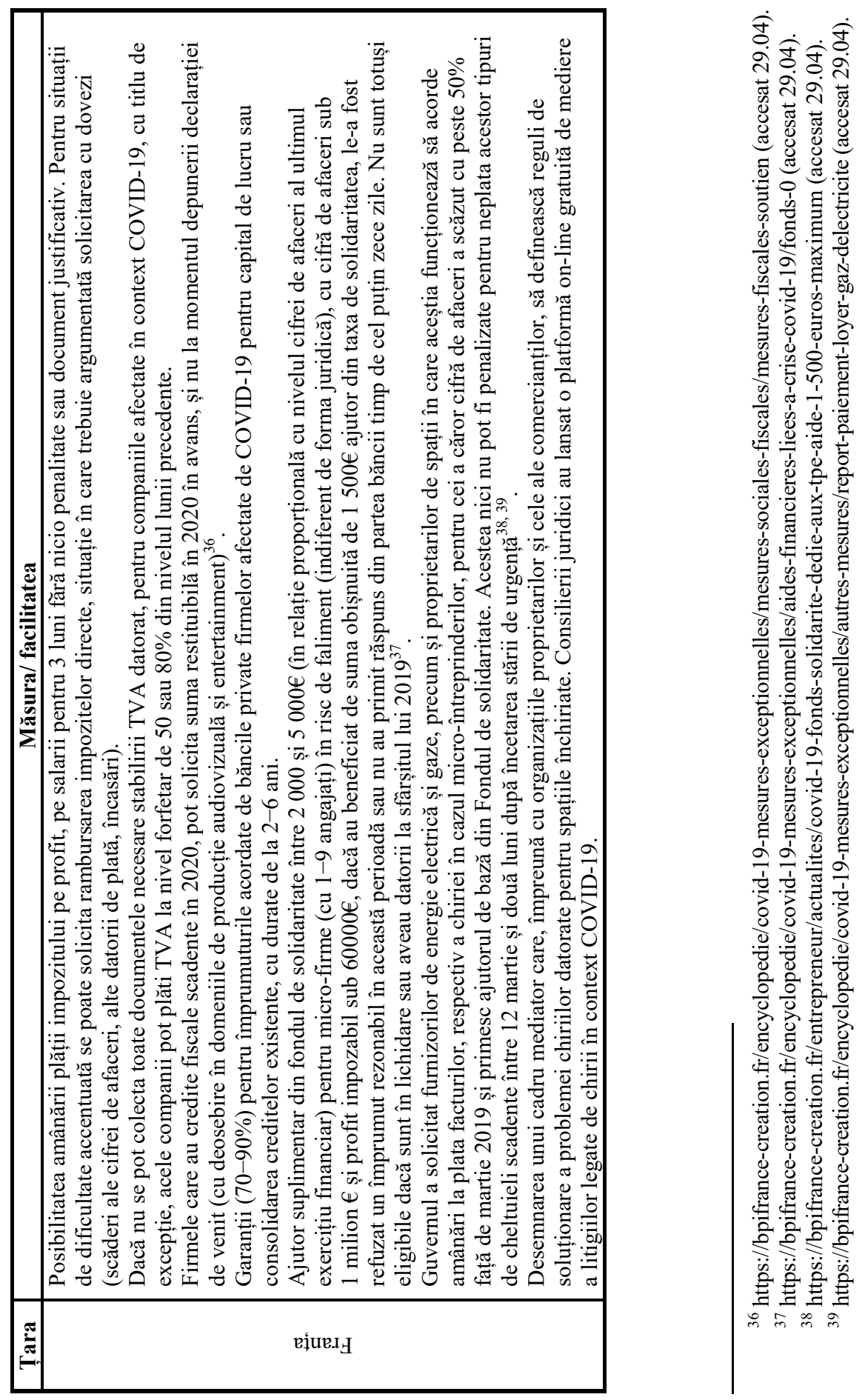


\section{BIBLIOGRAFIE}

Baldwin R., Weder di Mauro B. (2020) Introduction în Mitigating the COVID Economic Crisis: Act Fast and Do Whatever it Takes, Baldwin R., Weder di Mauro B. (eds), A VoxEU.org Book, CEPR Press

Boeri, T. (2002) Let Social Policy Models Compete and Europe Will Win, conference paper at Transatlantic perspectives on us-eu economic relations: convergence conflict and cooperation, Harvard, John F. Kennedy School of Government, 11-12 April 2002 https://sites.hks.harvard.edu/m$\mathrm{rcbg} /$ Conferences/useurelations/boeri_us_european_trends.pdf.

Cahuc P. (2019) Short-time work compensation schemes and employment, IZA World of Labor, $11 \mathrm{v} 2$, wol.iza.org

Esping-Andersen, G. (1999) Social Foundations of Post-Industrial Economics, Oxford New York: Oxford University Press,

Eurofound (2020), Living, working and COVID-19: First findings - April 2020, Dublin.

Hijzen, A., Venn D. (2011) The Role of Short-Time Work Schemes during the 2008-09 Recession. OECD Social, Employment and Migration Working Papers, No. 115. OECD Publishing, 2011

Ilie S. (2017) Venituri și performanță în politica socială, Calitatea Vieții, XXVIII, nr. 4, p. 351-369

Ilie S., Preoteasa A.M. (2017) O perspectivă asupra ocupării atipice: România în comparație europeană, Revista Calitatea Vieții, XXVIII, nr.3, p.243-266

Ilie S. (2018) Households' income in Romania for the 1918-2018 century: resources and social protection, Calitatea Vieții XXIX, nr. 2, p. 161-200

ILO (2020) ILO Monitor: COVID-19 and the world of work. Third edition.

INS (2020a) Evaluarea impactului COVID-19 asupra mediului economic în lunile martie și aprilie 2020, Comunicat de presă nr. 104/ 15 aprilie 2020 https://insse.ro/cms/sites/default/files/ cercetare_impactul_covid19_asupra_mediului_economic.pdf

INS, 2020b, Turismul în luna martie 2020, Comunicat de presă, nr. 116/5 mai https:// insse.ro/cms/sites/default/files/com_presa/com_pdf/turism03r20_0.pdf

INS, 2020c, Cifra de afaceri din comerţul cu amănuntul în luna martie 2020, nr. 117/6 mai https://insse.ro/cms/sites/default/files/com_presa/com_pdf/com_amanunt_03r20_0.pdf

Joyce R., Xu X. (2020) Sector shutdowns during the coronavirus crisis: which workers are most exposed, Institute for Fiscal Studies, IFS Briefing Note BN278

Schulten T., Müller T. (2020) Kurzarbeitergeld in der Corona-Krise, Aktuelle Regelungen in Deutschland und Europa, Policy Brief, No. 38 · Policy Brief WSI · 04/2020, Hans-Böckler-Stiftung

Stănculescu M., Marin M., Hommes G. (2009) The informal economy in Romania în 2009, Research Report, National Project „Economic Statistics Development” INS and EU, PHARE2005/017553.03.07.02, February 2009

Baza de date statistice folosite: CNPP https://www.cnpp.ro/web/guest/indicatori-statistici-pilon-i; INS http://statistici.insse.ro:8077/tempo-online); Eurostat https://ec.europa.eu/eurostat)

he paper draws attention to the impact of the COVID-19
context on the labor market. Based on the secondary data
analysis, a classification of the economic branches regarding the risk of affecting the activity is sketched. The higher risk tends to complement other employment vulnerabilities (lower wage level, higher share of selfemployment). The Romanian protective measures of employment and incomes fit the European practices of the current context. However, there is a risk of not being able to respond adequately to the increase of poverty and inequality.

Keywords: labour market inequalities; social policies; COVID-19. 